University of Louisville

ThinkIR: The University of Louisville's Institutional Repository

Electronic Theses and Dissertations

$12-2011$

\title{
Root coverage comparing acellular dermal matrix to connective tissue graft using the coronally positioned tunnel technique.
}

Marie-Eve Girouard

University of Louisville

Follow this and additional works at: https://ir.library.louisville.edu/etd

\section{Recommended Citation}

Girouard, Marie-Eve, "Root coverage comparing acellular dermal matrix to connective tissue graft using the coronally positioned tunnel technique." (2011). Electronic Theses and Dissertations. Paper 500.

https://doi.org/10.18297/etd/500

This Master's Thesis is brought to you for free and open access by ThinkIR: The University of Louisville's Institutional Repository. It has been accepted for inclusion in Electronic Theses and Dissertations by an authorized administrator of ThinkIR: The University of Louisville's Institutional Repository. This title appears here courtesy of the author, who has retained all other copyrights. For more information, please contact thinkir@louisville.edu. 


\title{
ROOT COVERAGE COMPARING ACELLULAR DERMAL MATRIX TO CONNECTIVE TISSUE GRAFT USING THE CORONALLY POSITIONED TUNNEL TECHNIQUE
}

\author{
By \\ Marie-Eve Girouard \\ D.M.D, University of Montreal Dental School, 2008
}

\author{
A Thesis \\ Submitted to the Faculty of the \\ School of Dentistry of the University of Louisville \\ In Partial Fulfillment of the Requirements \\ For the Degree of
}

Master of Science

Program in Oral Biology

School of Dentistry

University of Louisville

Louisville, Kentucky

December 2011 


\title{
ROOT COVERAGE COMPARING ACELLULAR DERMAL MATRIX TO CONNECTIVE TISSUE GRAFT USING THE CORONALLY POSITIONED TUNNEL TECHNIQUE
}

\author{
By \\ Marie-Eve Girouard \\ D.M.D., University of Montreal Dental School, 2008
}

A Thesis Approved on

October 11, 2011

By the Following Reading Committee

Henry Greenwell, Thesis Director

Margaret Hill

R. Vidal 


\section{DEDICATION}

This manuscript is dedicated to my marvelous family who have given me unwavering support throughout my career and continue to inspire me daily. 


\section{ACKNOWLEDGEMENTS}

I would like to express my sincere gratitude to the following individuals:

Dr. Henry Greenwell, Program Director of Graduate Periodontics, for his invaluable guidance and mentoring in my training as a periodontist, for his endless effort in advancing the Art and Science of Periodontology, and for his help in the preparation of this thesis.

Dr. Margaret Hill, Assistant Program Director, for her inspiration, continuous encouragement and guidance of all the residents. 


\begin{abstract}
ROOT COVERAGE COMPARING ACELLULAR DERMAL MATRIX TO CONNECTIVE TISSUE GRAFT USING THE CORONALLY POSITIONED TUNNEL TECHNIQUE

Marie-Eve Girouard, DMD
\end{abstract}

October 11, 2011

\begin{abstract}
Aims. The primary aim of this randomized, blinded, controlled clinical trial was to compare the percent root coverage obtained using acellular dermal matrix allograft and connective tissue graft using the coronally positioned tunnel technique 4 months postsurgically.
\end{abstract}

Methods. Twenty-four patients with 1 site of $\geq 3 \mathrm{~mm}$ Miller Class I or II recession were treated and followed for 4 months. Twelve patients received a coronally positioned tunnel plus ADM and were considered the test group. The positive control group consisted of 12 patients treated with a coronally positioned tunnel technique plus connective tissue graft and were considered the control group. Patients were randomly selected by a coin toss to receive either the test or control treatment.

Results. The mean facial recession defect at the initial exam for the ADM group was $3.1 \pm 0.3 \mathrm{~mm}$ which was reduced to $0.1 \pm 0.3 \mathrm{~mm}$ at the 4 month exam for a gain of 
$3.0 \pm 0.4 \mathrm{~mm}$ or $97 \%$ defect coverage $(\mathrm{p}<0.05)$. The mean facial recession defect at the initial exam for the CT group was $3.0 \pm 0.1 \mathrm{~mm}$ which was reduced to $0.2 \pm 0.6 \mathrm{~mm}$ at the 4 month exam for a gain of $2.8 \pm 0.4 \mathrm{~mm}$ or $95 \%$ defect coverage $(\mathrm{p}<0.05)$. There were no statistically significant differences between groups $(p>0.05)$. Probing depth increased $0.1 \mathrm{~mm}$ for both groups $(\mathrm{p}>0.05)$ from baseline to 4 months. Clinical attachment level increased $3.0 \mathrm{~mm}$ for the ADM group $(\mathrm{p}<0.05)$ and $2.9 \mathrm{~mm}$ for the CT group $(\mathrm{p}<0.05)$ at the 4-month final measurement. Mean keratinized tissue increased 0.3 $\mathrm{mm}$ for the ADM group $(\mathrm{p}>0.05)$ and $0.4 \mathrm{~mm}$ for the CT group $(\mathrm{p}>0.05)$. Creeping attachment was $0.1 \mathrm{~mm}$ for the ADM group ( $\mathrm{p}>0.05)$ and $0.2 \mathrm{~mm}$ for the CT group ( $\mathrm{p}>$ 0.05 ) at the 4-month final measurement.

Conclusions. The coronally positioned tunnel plus ADM produced $97 \%$ defect coverage while the coronally positioned tunnel plus CT produced $95 \%$ defect coverage. 


\section{TABLE OF CONTENTS}

PAGE

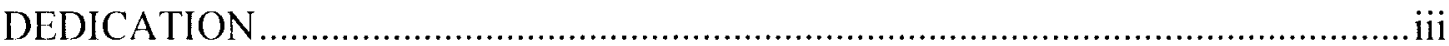

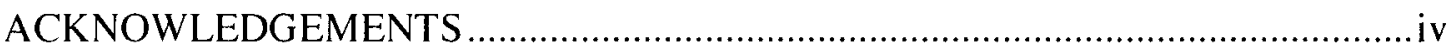

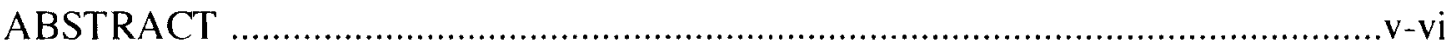

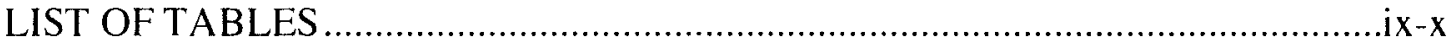

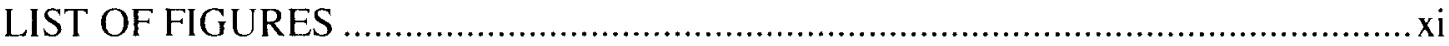

\section{CHAPTER}

\section{LITERATURE REVIEW}

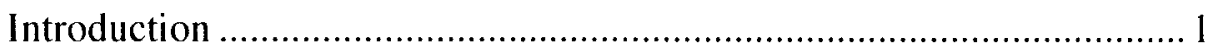

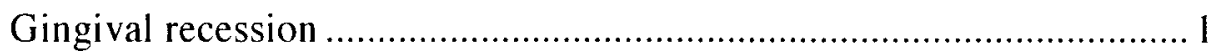

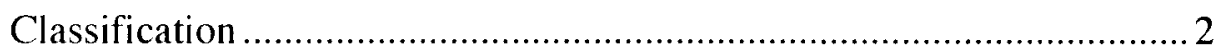

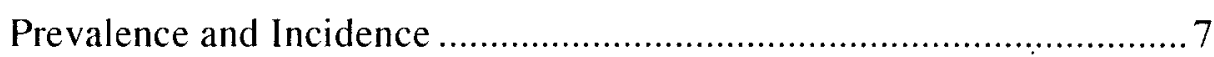

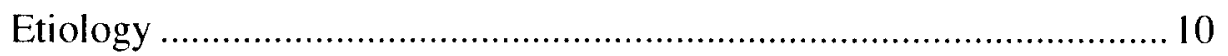

Progression and Anatomy .............................................................. 13

Clinical Studies with Connective Tissue Graft ................................... 14

Clinical Studies with CTG combined with CPF ................................ 19

Clinical Studies with CTG combined with CPF including smokers ......21

Palatal Anatomy .......................................................................... 22

Clinical Studies with of Coronally Positioned Flap ............................. 23

Clinical Studies with of CPF including smokers ..................................2 27

Clinical Studies with Acellular Dermal Matrix Allograft .....................27

Histology of Connective Tissue Graft ...................................................30

Histology of Coronally Positioned Flap ............................................. 32

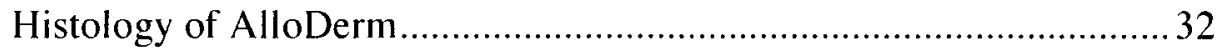

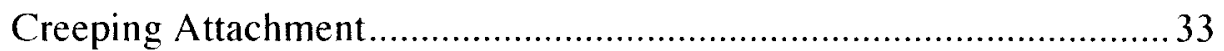

The significance of tissue thickness in root coverage procedures ..........34 
II. MATERIALS AND METHODS

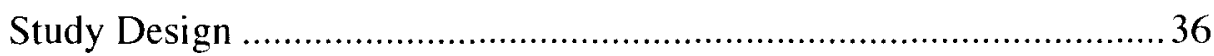

Patient Selection: Inclusion and Exclusion Criteria ........................... 37

Pre-surgical treatment ..................................................................... 37

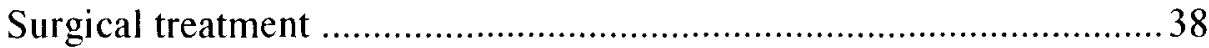

Post-surgical management.......................................................... 39

Visual analog scale of pain and esthetic outcomes ........................... 40

Four-month evaluation ............................................................... 40

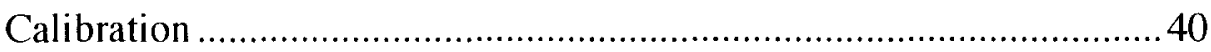

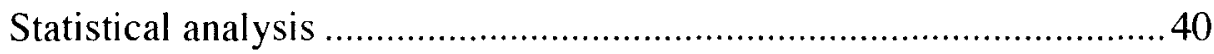

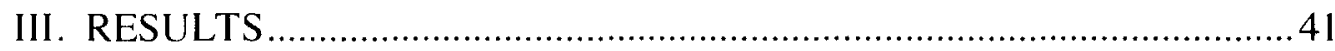

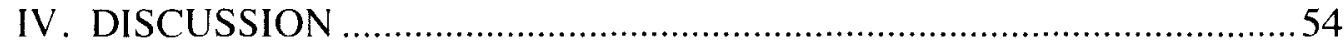

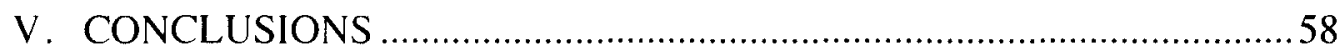

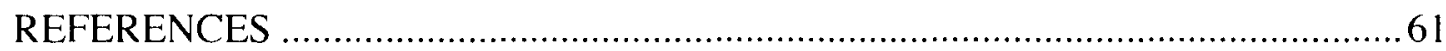

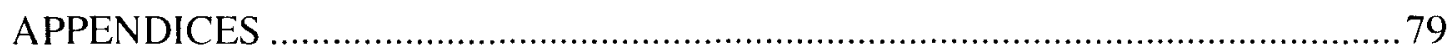

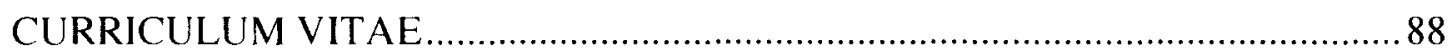




\section{LIST OF TABLES}

$\begin{array}{lll}\text { TABLE } & \text { PAGE }\end{array}$

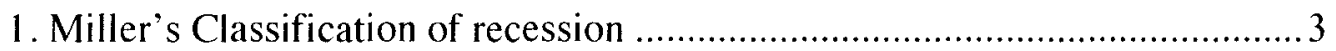

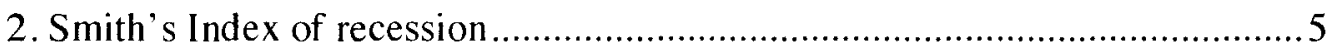

3. Pini Prato's Classification of root surface discrepancies ...........................6

4. Gorman's Distribution of teeth with gingival recession .......................... 8

5. Percent prevalence of persons with recession by age group .......................... 9

6. Percent prevalence of teeth with recession by age group .......................... 9

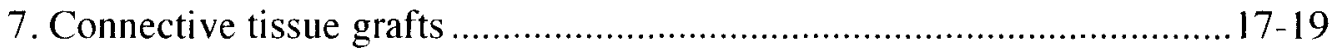

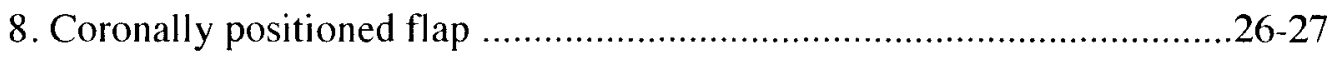

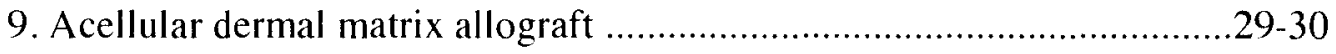

10. Clinical Indices for Test and Control Sites ........................................44

11. Probing Measurements for Test and Control Sites ...............................45

12. Creeping Attachment Mid-buccal .........................................................46

13. Recession depth vs. dehiscence depth .........................................4 47

14. Recession, defect coverage, root coverage for the Alloderm group ...........48

15. Recession, defect coverage, root coverage for the CT Graft group.............49

16. Visual Analog Scale of Pain and Esthetic Outcomes ................................50

17. CT vs. ADM Studies: ADM Results ..........................................................51

18. CT vs. ADM Studies: CT Results.......................................................52 
19. Summary Table of Tunnel Maxillary vs. Mandibular Sites .........................53 


\section{LIST OF FIGURES}

\section{FIGURE}

PAGE

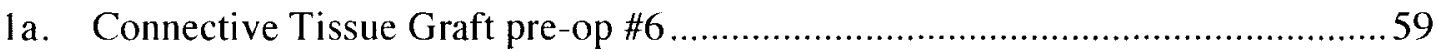

1b. Connective Tissue Graft 4-month post-op \#6 ...................................................59

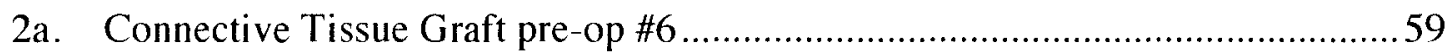

2b. Connective Tissue Graft 4-month post-op \#26 .................................................59

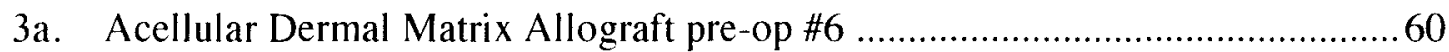

3b. Acellular Dermal Matrix Allograft 4-month post-op \#6 ..................................60

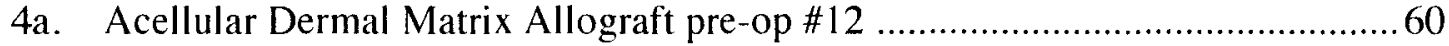

4b. Acellular Dermal Matrix Allograft post-op \#12 ...............................................60 


\section{CHAPTER I}

\section{LITERATURE REVIEW}

\section{INTRODUCTION}

In the field of periodontics, an array of different mucogingival procedures and materials are being studied. Today's society has increased esthetic standards, and exposed root surfaces are considered unacceptable to many. Furthermore, denuded roots are more prone to caries and hypersensitivity. The early root coverage procedures utilized the patient's own tissue and were thus limited in the extent of teeth involved per surgery. Drawbacks from these early root coverage techniques have motivated periodontists to test new methods and materials. With the advent of new materials, patients now have the option of undergoing single versus multiple surgeries to cover numerous recession defects.

Some patients are more susceptible to gingival recession than others. The need for improved and predictable root coverage procedures is great. Recession is common, and esthetics are in high demand. Thus, root coverage technology and techniques continue to improve.

\section{GINGIVAL RECESSION}

The American Academy of Periodontology defined gingival recession as the 
location of the gingival margin apical to the cementoenamel junction (Glossary of Periodontal Terms, 2001). In 1999, Armitage classified gingival recession under the category of Developmental or Aquired Deformities and Conditions, using the subcategory of mucogingival deformities and conditions around teeth. Treatment options for these mucogingival deformities include root coverage and gingival augmentation.

Gingival augmentation is defined as a procedure aimed at increasing the amount of keratinized tissue (American Academy of Periodontology, Glossary of Periodontal Terms, 2001). Gingival augmentation may be used in the presence or absence of gingival recession. Many early studies have examined the use of free gingival grafts as a method to increase the amount of keratinized tissue (Bjorn 1963, Nabers 1966).

\section{Classification}

A large variety of classification systems for recession have been described over the years. The more notable include Ariaudo (1966), Sullivan and Atkins (1968), Miller (1985), and Smith (1997). Every classification system takes into consideration gingival anatomy and architecture, recession severity and response to treatment. However, they each put emphasis on different recession details.

Ariaudo (1966) strongly considered probe depth and periodontal health in his classification system. His system consists of three classes. Class I is an exposed root surface without periodontal pockets; $100 \%$ root coverage is expected. Class II is an exposed root surface with slight pocketing on adjacent teeth; $100 \%$ root coverage cannot

be expected and some loss of gingival coverage of adjacent teeth will result. Class III is an exposed root surface with a deep pocket on the recipient site and/or adjacent teeth; 
minimal coverage may be achieved. Sullivan and Atkins (1968) classified recession in general terms as shallow or deep, and narrow or wide. Combination terms would be shallow narrow, shallow wide, deep narrow, and deep wide. Response to treatment and predictability worsen as the defect progresses from shallow narrow to deep wide. Today, the most widely used classification system is the one described by Miller (1985). In his classification (Table 1), he took into consideration the relationship between the gingival margin and the mucogingival junction, as well as the interproximal alveolar crest and soft tissue height.

Table 1

Miller's Classification of Recession

Miller (1985)

\begin{tabular}{|c|l|}
\hline Class & Description \\
\hline I & $\begin{array}{l}\text { Gingival margin does not extend to the mucogingival junction. No bone } \\
\text { or soft tissue loss interproximally; 100\% root coverage can be expected. }\end{array}$ \\
\hline II & $\begin{array}{l}\text { Gingival margin extends to or beyond the mucogingival junction. No } \\
\text { bone or soft tissue loss interproximally; 100\% root coverage can be } \\
\text { expected. }\end{array}$ \\
\hline III & $\begin{array}{l}\text { Gingival margin extends to or beyond the mucogingival junction. Bone } \\
\text { or soft tissue loss is present interproximally, or there is malpositioning } \\
\text { of the teeth; partial root coverage can be expected. }\end{array}$ \\
IV & $\begin{array}{l}\text { Gingival margin extends to or beyond the mucogingival junction. } \\
\text { Severe bone or soft tissue loss interproximally, and/or malpositioning of } \\
\text { teeth; root coverage cannot be expected. }\end{array}$ \\
\hline
\end{tabular}


Smith (1997) classified recession using a double digit Index of Recession (IR) that considered the horizontal (first number) and vertical (second number), as well as the facial $(\mathrm{F})$ and lingual $(\mathrm{L})$, component. A succeeding asterisk indicated the involvement of the mucogingival junction. (Table 2). 
Table 2

Index of Recession (RI)

Smith (1997)

\begin{tabular}{|c|c|c|}
\hline Component & Class & Description \\
\hline \multirow[t]{6}{*}{ Horizontal } & $\mathbf{0}$ & No clinical evidence of root exposure \\
\hline & 1 & $\begin{array}{l}\text { As } 0 \text {, but subjective awareness of sensitivity to air and / or } \\
\text { exposure of CEJ for up to } 10 \% \text { of the M-D distance }\end{array}$ \\
\hline & 2 & Exposure of the CEJ $>10 \%-\leq 25 \%$ of the M-D distance \\
\hline & 3 & Exposure of the CEJ $>25 \%-\leq 50 \%$ of the M-D distance \\
\hline & 4 & Exposure of the CEJ $>50 \%-\leq 75 \%$ of the M-D distance \\
\hline & 5 & Exposure of the CEJ $>75 \%-\leq 100 \%$ of the M-D distance \\
\hline \multirow[t]{4}{*}{ Vertical } & $\mathbf{0}$ & No clinical evidence of root exposure \\
\hline & 1 & $\begin{array}{l}\text { As } 0 \text {, but subjective awareness of sensitivity to air and / or } \\
\text { exposure of the CEJ not exceeding }>1.0 \mathrm{~mm} \text { vertically to the } \\
\text { gingival margin }\end{array}$ \\
\hline & $2-8$ & $\begin{array}{l}\text { Root exposure } 2-8 \mathrm{~mm} \text { extending vertically from the CEJ to } \\
\text { the base of soft tissue defect }\end{array}$ \\
\hline & 9 & $\begin{array}{l}\text { Root exposure }>8.0 \mathrm{~mm} \text { from the CEJ to base of soft tissue } \\
\text { defect }\end{array}$ \\
\hline \multirow[t]{2}{*}{ Asterisk } & Present & $\begin{array}{l}\text { Vertical component encroaches into the MGJ or beyond into } \\
\text { alveolar mucosa }\end{array}$ \\
\hline & Absent & Absence or non-involvement of MGJ \\
\hline
\end{tabular}


Pini Prato et al. (2010a) developed a hard tissue classification system to complement Miller's classification. Miller's system evaluates different degrees of damage to periodontal tissues, but does not consider the condition of the exposed root surface: presence of an identifiable cemento-enamel junction (CEJ) and presence of root abrasion. If the CEJ is not identifiable, clinicians encounter difficulties in accurately measuring the depth and the width of recessions during diagnostic phase. To develop this new system, two variables were considered: CEJ and cervical discrepancies. Considering the presence of the CEJ on the buccal surface, two classes were identified: Class A, identifiable CEJ on the entire buccal surface; and Class B, unidentifiable CEJ totally or partially. Considering the presence of cervical discrepancies (step), measured with a periodontal probe perpendicular to the long axis of the tooth in the deepest point of the abrasion, two classes were identified: Class $(+)$, presence of cervical step $(>0.5 \mathrm{~mm})$ involving the root or the crown and the root; and class (-), absence of cervical step. Therefore, a working classification identifies four different conditions (Table 3).

\section{Table 3}

Classification System of Four Different Classes of Root Surface Discrepancies Pini Prato et al. (2010a)

\begin{tabular}{|c|c|}
\hline Class & Descriptions \\
\hline Class A + & CEJ visible, with step \\
\hline Class A - & CEJ visible, without step \\
\hline Class B + & CEJ not visible, with step \\
\hline Class B - & CEJ not visible, without step \\
\hline
\end{tabular}


Stoner and Mazdyasna (1980), in a study of 1003 children of approximately 15 years old, defines pseudorecession and differentiates it from true recession. True recession has been previously defined by the $\mathrm{AAP}$ as the gingival margin located apically to the cenamoenamel junction. Pseudorecession is defined as the gingival margin located more apically than the gingival margins of adjacent teeth, but properly located coronally to the cementoenamel junction.

\section{Prevalence and Incidence}

Kitchin (1941) was the first author to study the prevalence and extent of tooth root exposure in different age classes. From a study of the teeth of 200 individuals, the occurrence of cervical exposure was found to vary from $15.5 \%$ of all teeth in the $20-29$ age class to $57.7 \%$ of the teeth in the 50-59-age class. Gorman (1967) examined 164 people to determine the prevalence and incidence of gingival recession. Four groups were

formed by age classification: 16-25 years, $26-35$ years, $36-45$ years, $46-86$ years. The three youngest age groups demonstrated recession more frequently on the maxillary cuspid and bicuspid facial tooth surfaces. In the oldest age group, recession was found more frequently on the facial surfaces of the cuspid and bicuspid teeth but with about equal frequency in the maxilla and mandible (Table 4). The occurrence of recession was found to vary from $54.5 \%$ of all subjects in the $16-26$ age group to $100 \%$ of the subjects in the 46-86 age group. 


\section{Table 4}

Distribution of Teeth with Gingival Recession

Gorman (1967)

\begin{tabular}{|c|c|c|c|c|c|c|c|}
\hline $\begin{array}{c}\text { Age } \\
\text { Group }\end{array}$ & Maxilla & Mandible & Incisor & $\begin{array}{c}\text { Canine } \\
\text { and } \\
\text { Premolar }\end{array}$ & Molar & Facial & Lingual \\
\hline $\begin{array}{c}\mathbf{1 6 - 2 5} \\
\text { yrs. }\end{array}$ & 119 & 86 & 19 & 132 & 54 & 203 & 2 \\
\hline $\begin{array}{c}\mathbf{2 6 - 3 5} \\
\text { yrs. }\end{array}$ & 130 & 93 & 27 & 133 & 63 & 223 & 0 \\
\hline $\begin{array}{c}\mathbf{3 6 - 4 5} \\
\text { yrs. }\end{array}$ & 157 & 120 & 72 & 147 & 58 & 257 & 20 \\
\hline $\begin{array}{c}\mathbf{4 6 - 8 6} \\
\text { yrs. }\end{array}$ & 138 & 136 & 76 & 127 & 71 & 247 & 27 \\
\hline
\end{tabular}

Serino et al. (1994) conducted a 12-year cross-sectional and longitudinal study evaluating the prevalence and the development/progression of attachment loss and gingival recession at buccal tooth surfaces in a population with high standard of oral hygiene. His second objective was to study the relationship between attachment loss and gingival recession. Subjects were devided into four cohorts based upon age at the baseline evaluation: $18-29,30-41,42-53$ and $54-65$ years. First of all, in all age groups the frequency of buccal sites with $\geq 2 \mathrm{~mm}$ attachment loss increased during the course of the 12-year of follow-up but the most marked increase was observed in the youngest age group (from $19 \%$ to $48 \%$ ). In the two youngest age groups, at the 12-year follow-up, the most pronounced frequency of recession was recorded at maxillary/mandibular incisors and canines. In the two oldest age groups maxillary molars and premolars and mandibular incisors and premolars were the most commonly affected. Second of all, he found that if 
the attachment level (AL) was $>2 \mathrm{~mm}$, additional recession was more common. For 3 $\mathrm{mm} \mathrm{AL}, 67 \%$ of sites had additional recession; and $\geq 4 \mathrm{~mm} \mathrm{AL}$ had $98 \%$ sites with additional recession. In summary, prevalence of recession increased with age, and sites with initial recession were more susceptible to additional recession. In a classic article utilizing data from the NHANES III, 1988-1994, US (Table 5, 6) to present the prevalence of gingival recession in $\geq 30$ year-olds. Albandar (1999) found $23 \%$ had at least $3 \mathrm{~mm}$ recession. He categorized those adults with $\geq 3 \mathrm{~mm}$ recession by age group: $10 \%$ for $30-39$ year-olds, $18 \%$ for $40-49,30 \%$ for $50-59,40 \%$ for $60-69,46 \%$ for $70-79$, and $60 \%$ for $80-90$. Overall, each decade of life results in approximately a $10 \%$ increase in the prevalence of gingival recession.

Table 5

Percent Prevalence of Persons with recession by Age Group Albandar (1999)

\begin{tabular}{|c|c|c|c|c|}
\hline Age/recession & $\mathbf{3 0 - 3 9}$ & $\mathbf{4 0 - 4 9}$ & $\mathbf{5 0 - 5 9}$ & Mean \\
\hline$\geq \mathbf{1 ~} \mathbf{~ m}$ & 38 & 57 & 71 & 58 \\
\hline$\geq \mathbf{3 ~} \mathbf{~ m}$ & 10 & 18 & 30 & 22 \\
\hline$\geq \mathbf{5} \mathbf{~ m m}$ & 2 & 4 & 7 & 6 \\
\hline
\end{tabular}

Table 6

Percent Prevalence of Teeth with Recession by Age Group Albandar (1999)

\begin{tabular}{|c|c|c|c|c|}
\hline Age/recession & $\mathbf{3 0 - 3 9}$ & $\mathbf{4 0 - 4 9}$ & $\mathbf{5 0 - 5 9}$ & Mean \\
\hline$<\mathbf{1 ~ \mathbf { ~ m }}$ & 36 & 58 & 75 & 56 \\
\hline$\geq \mathbf{1 ~} \mathbf{m m}$ & 9 & 18 & 32 & 22 \\
\hline $\mathbf{3} \mathbf{~ m m}$ & 1 & 2 & 5 & 3 \\
\hline
\end{tabular}


Loe et al. (1992) examined the prevalence of recession over 20 years among Norwegian scholars and Sri Lankan tea workers and emphasized different types of recession among the populations: facial, found mostly with good oral hygiene, and interproximal, found mostly with periodontitis. The Norwegians presented with higher oral hygiene scores and recession was found to be $\geq 60 \%$ facial for age $20,70 \%$ mostly facial for age 30 , and $\geq 90 \%$ mostly facial for 50 year-olds. The Sri Lankans presented with lower oral hygiene scores and recession was found to be $\geq 30 \%$ for those younger than age $20 ; 90 \%$ facial, lingual and interproximally for age $30 ; 100 \%$ for age 40 ; and by age 50 , all had recession facial (70\%), lingual (50\%), and interproximally $(40 \%)$. In comparing populations of different hygiene levels, it is obvious that those with a high level of hygiene develop recession due to mechanical factors (facial/lingual recession) only while maintaining a state of health, whereas the other population developed recession largely due to inflammatory factors present with a state of periodontitis (interproximal recession). Hugoson and Norderyd (2008) examined a large random Swedish population from 1973-2003 and found that the frequency of tooth surfaces with gingival recession increased from $0 \%$ in 20 -year-old subjects to $22.2 \%$ in 80 -year-old subjects. This agrees with the observation from other studies that the prevalence of gingival recession increases with age.

\section{Etiology}

As described previously, there are only two main types of recession but many theories were postulated on the actual cause. Loe (1992) described the two main types of recession: 1) facial/lingual recession more commonly found in patients with a healthy 
interproximal periodontium and no interproximal recession. 2) inteproximal recession, associated with a disease state of periodontitis. In an informational paper, Greenwell (2005) expanded on these two types of recession: facial recession occurs in patients with a high level of personal and professional dental care, while chronic periodontitis, with its more generalized recession, is a disease associated with plaque and calculus. Hirschfeld (1931), reported on gingival recession through toothbrush trauma. According to him, the following elements may induce recession through toothbrush trauma: 1) anatomic abnormalities, 2) stiffness of bristles, 3) size and briskness of the brush strokes. In the same vein, Kitchin (1941) found that in both the good and poor hygiene groups, areas receiving more brushing showed progressively increased abrasion. Gartrell and Matthews (1976) listed two major factors involved in the process of recession: 1) anatomical factors such as alveolar bone dehiscence and presence of attached gingiva, 2) irritating factors such as mechanical trauma, plaque and tooth movement. Gorman (1967) conducted a study to determine the prevalence and incidence of gingival recession and to correlate recession with apparent clinical factors. The etiologic factors which appeared to be related to gingival recession were found in the following order of frequency: 1) malalignment, 2) toothbrush trauma, 3) calculus, 4) inflammation, 5) disuse, 6) occlusal trauma, 7) flat crown curvature, 8) high frenum attachment, 9) cervical fillings, 10) crown impingement, 11) clasp trauma. Stewart (1976) was the first author to report on gingival recession as a result of self-inflicted (factitial) injuries. He named this condition gingivitis artefacta (minor and major). Pattison (1983) in a literature review on the same topic found that only 49 cases had been reported from 1949 to 1983 . Most occur in children 12 years or younger ( $78 \%$ ) and most often involve women. 
Steiner et al. (1981) used the monkey model to study tissue alterations taking place at incisors which were either exposed to tipping and extrusion movements or bodily movements in labial direction. These movements resulted in recession of the labial gingival margin and in loss of attachment. They suggested that tension in the marginal soft tissue created by the forces applied to the teeth could be the cause. Using the same monkey model, Wennstrom et al. (1987) suggested that plaque-induced inflammation and the thickness (volume) of the marginal soft tissue, rather than the apico-coronal width of the keratinized and attached gingiva, are determining factors for the development of recession and attachment loss during orthodontic tooth movement. However, when the tooth can be moved within the envelope of the alveolar process, the risk of harmful sideeffects on the gingival tissue is minimal, irrespective of the dimensions of the soft tissues.

Some authors have linked the development of recession to an inflammatory process. Stillman (1921), reported on the "Stillman's cleft" which appears in the marginal gingiva due to traumatic occlusion. Staffileno (1964) reported that focal gingival recession was generally associated with inflammatory periodontal disease. Histologically, Baker and Seymour (1976) reported on the stages in the pathogenesis of gingival recession in a rat model in which pocketing had been induced by replacement of natural incisors with dental implants. Suitable conditions were thus created on the palatal aspect of the implant sockets for recession to occur. Heat-cured acrylic resin implants of different sizes were made to replace an upper incisor. Three recognizable zones were observed on the palatal aspect of the implant socket and corresponded to different stages of the process. Zone 1: most apical portion and was used as the control zone. The rete pegs of the oral epithelium and the pocket-lining epithelium were of normal configuration 
and had not elongated into the intervening connective tissue. Zone 2: as the thickness of the connective tissue between the oral epithelium and pocket-lining epithelium became less, widening of the spinous layers and elongation of the rete pegs was evident. Elongating rete pegs were surrounded by mononuclear cell infiltration. A surface groove was formed. Zone 3: the epithelial layers were fully matured and were separated by a narrow cleft. In conclusion, the study suggests that gingival recession involves a localized inflammatory process which causes breakdown of connective tissue and leads to proliferation of the epithelium into the site of connective tissue destruction. Pini Prato et al. (2002) wrote a case report on gingival recession induced by HSV-1 virus. This type of recession was accompanied by marginal inflammation of the gingiva and vesicle formation. In a case report, Green and Levin (1973) reported that genetics play a major role in the etiology of gingival recession. A familial study revealed progressive stages of gingival recession in the mandibular anterior region of three successive generations of females in the direct maternal line.

Numerous contributing factors have been linked to gingival recession but toothbrush trauma is thought to be the primary cause. However, there are many other factors to take into consideration such as factitial injuries, occlusion, malalignment, frenum position, orthodontics, genetics and viral infections.

\section{Progression and Anatomy}

In a study on dry skulls, Hirschfeld (1923) found that anatomical variations are very often responsible for root exposure. He concluded that a large number of cases of alveolar deficiency and root exposure are strictly nonpathologic in origin and mainly an 
expression of mechanical wear and anatomic variation (very thin alveolar plate). Gartrell and Mathews (1976) stated that recession of the gingiva is probably dependent on the existence or creation of dehiscences of the alveolar bone. Löst (1984) studied the depth of alveolar bone dehiscences in relation to gingival recessions and found that the mean difference between the gingival margin and the depth of the osseous dehiscence was 2.67 $\mathrm{mm}$. Also, for each $1.0 \mathrm{~mm}$ increase in recession depth there was a corresponding increase of $0.98 \mathrm{~mm}$ in the alveolar bone dehiscence. Serino et al. (1994) found that if attachment loss of $>3 \mathrm{~mm}, 67 \%$ of the buccal surfaces had recession. If attachment loss was $\geq 4 \mathrm{~mm}, 98 \%$ of the buccal surfaces had recession. He also found that proportion of subjects with recession increases with age.

\section{ROOT COVERAGE}

\section{Clinical studies with Connective Tissue Graft (CTG)}

The connective tissue graft has been considered the gold standard for root coverage as well as for soft tissue augmentation procedures. Results of numerous human studies (Table 7) span the length of up to five years post-operatively. CTG procedures produce a $87 \%$ mean root coverage (range $57 \%-98 \%$ ). Edel (1974) was the first author to report on the free connective tissue graft. The results of his study showed that a significant increase in attached gingiva can be achieved by grafting connective tissue alone. His study confirmed Karring et al. (1971) concept that it is the information in the connective tissue that determines the character of the surface epithelium. Langer and Calagna $(1980,1982)$ reported on the subepithelial connective tissue grafts for both preprosthetic soft tissue ridge augmentation and root coverage procedures. They were the 
first authors to use a CTG to attempt root coverage. Langer and Calagna's root coverage technique is performed as follows: the donor tissue is harvested using a trap door technique. At the recipient site, a partial thickness dissection is made on the radicular surface of the involved teeth. This will leave CT over the recipient tooth. Two vertical incisions are usually made. The CT graft is placed under the flap so that part of the donor CT and epithelium covers the receded surface. Langer and Langer (1985) published a more detailed article on the subepithelial connective tissue graft technique for root coverage only. They stated that graft survival was possibly due to double-blood supply coming from the underlying periosteum and the overlying flap. Raetzke (1985) used the "pouch" technique with a CT graft for localized recessions and reported a mean root coverage of $80 \%$. Nelson (1987) studied 14 patients with 29 recession sites utilizing a CTG and full thickness double pedicle technique for 42 months. He categorized the recession defect depth as mild $(1-3 \mathrm{~mm})$, moderate $(4-6 \mathrm{~mm})$, and advanced $(7-10 \mathrm{~mm})$. Mean root coverage obtained for each category was $100 \%, 92 \%$, and $88 \%$, respectively. Harris (1992) used the same technique as Nelson except that the pedicles were splitthickness. The procedure was applied to 20 patients with 30 Miller Class I and II defects and followed for three months. Mean root coverage obtained was 97\%. Harris (1994) used the same double pedicle technique on 74 patients with 100 Miller Class I or II recession sites and followed them for six months post-operatively. Mean root coverage obtained was $97.7 \%$. In the same article, he listed factors that could be associated with root coverage success or lack of success: 1) size of the pedicle, 2) previous free gingival graft and 3) plaque control during the postoperative period. He also reported a list of factors that did not appear to be related to root coverage. Bruno (1994) modified Langer 
and Langer's technique by eliminating the vertical releasing incisions. His rationale was that vertical incisions compromise the blood supply of the overlying tissue and cause cicatricial lines. He also eliminated the vertical incisions from the palatal harvest site and the graft included periosteum. Allen (1994a) described the original "tunnel" technique consisting of a supraperiosteal envelope and a CTG. The envelope is usually elevated split-thickness unless in the presence of thin gingiva where a full-thickness elevation would be required for tissue viability. In a second article, Allen (1994b) reported clinical results using the "tunnel" technique. Treatment of 23 sites in 12 patients resulted in mean root coverage of $84 \%$. Like Nelson, he categorized the recession defect depth as shallow (1-3 mm), moderate (4-6 mm), and advanced ( $7-10 \mathrm{~mm})$. Furthermore, he categorized the recession defect width as narrow $(2 \mathrm{~mm})$, moderate $(3 \mathrm{~mm})$, and wide $(4 \mathrm{~mm})$. Mean root coverage obtained for each recession width categories was $95 \%, 87 \%$, and $76 \%$, respectively. Blanes and Allen (1999) modified Allen's technique by combining the tunnel and double pedicle flap. The technique is primarily for mandibular anterior teeth with wide papillae. The midline papilla is left intact to prevent flap retraction. Zabalegui et al. (1999) used Allen's "tunnel" technique on multiple sites and reported a 92\% mean root coverage. 
Table 7

Connective Tissue Grafts

\begin{tabular}{|c|c|c|c|c|c|c|c|c|c|c|}
\hline Author & $\underline{\mathrm{Yr}}$ & $\frac{\text { Mea }}{\mathrm{n}}$ & Mean & $\underline{\underline{D i f f}}$ & $\underline{\mathrm{Rpt}}$ & $\frac{\text { Calc }}{\%}$ & \# Pts & 夰 & Time & Miller \\
\hline & & $\underline{\text { Init }}$ & $\underline{\underline{F i n}}$ & & $\frac{\text { Def }}{\text { Cov }}$ & $\begin{array}{l}\text { Def } \\
\text { Cov } \\
\end{array}$ & & & Mo & Class \\
\hline & & & & & & & & & & \\
\hline \multicolumn{11}{|l|}{$\begin{array}{l}\text { Connective } \\
\text { Tissue }\end{array}$} \\
\hline Raetzke & 1985 & 3.29 & 0.67 & 2.62 & 80 & 80 & 10 & 12 & 8 & NR \\
\hline Levine & 1991 & 3.86 & 0.14 & 3.72 & 97 & 96 & 11 & 21 & 3 & NR \\
\hline Harris & 1992 & 3.58 & 0.10 & 3.48 & 97 & 97 & 20 & 30 & 3 & I\& II \\
\hline Jahnke et al. & 1993 & 2.80 & 0.60 & 2.20 & 80 & 79 & 9 & 9 & 6 & I \& II \\
\hline Allen A & 1994 & 3.43 & 0.74 & 2.69 & 84 & 78 & 12 & 23 & 6 & I \& II \\
\hline Borghetti, Louise & 1994 & 3.66 & 1.09 & 2.57 & 71 & 70 & 15 & 15 & 12 & I\& II \\
\hline Bouchard et al. & 1994 & 4.53 & 1.60 & 2.93 & 65 & 65 & 15 & 15 & 6 & I\& II \\
\hline Bouchard et al. & 1994 & 4.20 & 1.27 & 2.93 & 70 & 70 & 15 & 15 & 6 & $I \& I I$ \\
\hline Harris & 1994 & 3.30 & 0.10 & 3.20 & 98 & 97 & 74 & 100 & 6 & I \& II \\
\hline Aranda & 1996 & 3.60 & 0.80 & 2.80 & 79 & 78 & 10 & 10 & 6 & NR \\
\hline Ricci et al. & 1996 & 4.88 & 1.05 & 3.83 & 77 & 78 & 18 & 18 & 12 & I \& II \\
\hline Tinti et al. & 1996 & 3.32 & 0.27 & 3.05 & 92 & 92 & 14 & 29 & 12 & I \& II \\
\hline Wennstrom et al. & 1996 & 4.00 & 0.10 & 3.90 & 99 & 98 & 67 & 58 & 24 & I \\
\hline Bouchard et al. & 1997 & 4.13 & 0.66 & 3.47 & 84 & 84 & 15 & 15 & 6 & I \& II \\
\hline Bouchard et al. & 1997 & 3.86 & 0.80 & 3.06 & 79 & 79 & 15 & 15 & 6 & I \& II \\
\hline Harris & 1997 & 3.70 & 0.10 & 3.60 & 97 & 97 & 10 & 10 & 6 & $I \& I I$ \\
\hline Paolantonio et al. & 1997 & 3.43 & 0.58 & 2.85 & 85 & 83 & 35 & 35 & 60 & I\& II \\
\hline Harris & $1998 \mathrm{a}$ & 3.60 & 0.20 & 3.40 & 95 & 94 & 12 & 19 & 6 & $1 \& 11$ \\
\hline Jepsen et al. & 1998 & 3.60 & 0.50 & 3.10 & 87 & 86 & 15 & 15 & 12 & I \& II \\
\hline Muller et al. & 1998 & 3.05 & 1.01 & 2.04 & 74 & 67 & 18 & 28 & 12 & $1 \& I 1$ \\
\hline Trombelli et al. & 1998 & 3.00 & 0.50 & 2.50 & 81 & 83 & 12 & 12 & 6 & $1 \& 11$ \\
\hline Zucchelli et al. & 1998 & 5.60 & 0.30 & 5.30 & 94 & 95 & 18 & 18 & 12 & $1 \& 11$ \\
\hline Borghetti et al. & 1999 & 3.85 & 0.96 & 2.89 & 76 & 75 & 14 & 14 & 6 & 1 \\
\hline Muller et al. & 1999 & 2.48 & 0.60 & 1.88 & 80 & 76 & 13 & 14 & 6 & I\& II \\
\hline Zabalegui et al. & 1999 & 3.38 & 0.33 & 3.05 & 92 & 90 & 4 & 21 & 12 & $1 \& 11$ \\
\hline Caffesse et al. & 2000 & 2.95 & 0.16 & 2.79 & 95 & 95 & 19 & 19 & 6 & I\& II \\
\hline Caffesse et al. & 2000 & 3.00 & 0.44 & 2.56 & 85 & 85 & 17 & 17 & 6 & I\& II \\
\hline Harris & 2000 & 3.40 & 0.20 & 3.20 & 96 & 94 & 25 & 42 & 3 & $1 \& I I$ \\
\hline Rosetti et al. & 2000 & 4.16 & 0.20 & 3.96 & 96 & 95 & 12 & 12 & 18 & I\& II \\
\hline Tatakis. Trombelli & 2000 & 2.50 & 0.10 & 2.40 & 96 & 96 & 12 & 12 & 6 & I\& II \\
\hline $\begin{array}{l}\text { Aichelmann- } \\
\text { Reidy et al. }\end{array}$ & 2001 & 3.00 & 0.80 & 2.20 & 74 & 73 & 22 & 22 & 6 & $1 \& I I$ \\
\hline Cordioli et al. & 2001 & 3.50 & 0.20 & 3.30 & 95 & 94 & 11 & 31 & 12 & I \& II \\
\hline Cordioli et al. & 2001 & 3.60 & 0.50 & 3.10 & 90 & 86 & 10 & 31 & 12 & I \& II \\
\hline Muller et al. & 2001 & 2.49 & 0.57 & 1.92 & 82 & 77 & 13 & 14 & 12 & I \& II \\
\hline Novaes et al. & 2001 & 2.97 & 1.13 & 1.84 & 65 & 62 & 9 & 9 & 6 & I \& II \\
\hline Romagna-Genon & 2001 & 3.76 & 0.57 & 3.19 & 85 & 85 & 20 & 20 & 6 & I \& II \\
\hline Wang et al. & 2001 & 3.40 & 0.70 & 2.70 & 84 & 79 & 16 & 16 & 6 & I\& II \\
\hline Harris & $2002 a$ & 3.70 & 0.10 & 3.60 & 98 & 97 & 100 & 122 & 3 & I \& II \\
\hline Harris & $2002 a$ & 3.50 & 0.20 & 3.30 & 96 & 94 & 100 & 144 & 3 & $1 \& 11$ \\
\hline Paolantonio & 2002 & 4.60 & 0.46 & 4.14 & 90 & 90 & 15 & 15 & 12 & I \& II \\
\hline Paolantonio et al. & 2002 & 4.80 & 0.53 & 4.27 & 89 & 89 & 15 & 15 & 12 & I\& II \\
\hline
\end{tabular}




\begin{tabular}{|c|c|c|c|c|c|c|c|c|c|c|}
\hline Harris & $2002 b$ & 3.82 & 0.08 & 3.74 & 98 & 98 & 100 & 146 & 28 & $I \& I I$ \\
\hline Tal et al. & 2002 & 4.86 & 0.57 & 4.29 & 89 & 88 & 7 & 7 & 12 & I\& II \\
\hline Lee et al. & 2002 & 3.67 & 0.33 & 3.34 & 91 & 91 & 15 & 21 & 36 & I-III \\
\hline Goldstein et al. & 2002 & 4.09 & 0.12 & 3.97 & 97 & 97 & 33 & 33 & 34 & I\& II \\
\hline Goldstein et al. & 2002 & 3.44 & 0.31 & 3.13 & 92 & 91 & 27 & 27 & 32 & I\& II \\
\hline Harris & 2003 & 4.40 & 0.50 & 3.90 & 91 & 89 & 50 & 50 & 3 & I\& II \\
\hline McGuire, Nunn & 2003 & 4.25 & 0.2 & 4.01 & 94 & 94 & 17 & 17 & 12 & I\& II \\
\hline Zucchelli et al. & 2003 & 4.00 & 0.10 & 3.90 & 97 & 98 & 15 & 15 & 12 & $1 \& \mathrm{II}$ \\
\hline Zucchelli et al. & 2003 & 3.90 & 0.30 & 3.60 & 95 & 92 & 15 & 15 & 12 & I\& II \\
\hline Cetiner et al. & 2003 & 3.80 & 0.60 & 3.20 & 86 & 84 & 30 & 20 & 12 & I\& II \\
\hline Al-Zahrani et al. & 2004 & 3.78 & 1.34 & 2.44 & 65 & 65 & 13 & 16 & 3 & I\& II \\
\hline Al-Zahrani et al. & 2004 & 3.94 & 1.69 & 2.25 & 57 & 57 & 13 & 16 & 3 & I\& II \\
\hline da Silva et al. & 2004 & 4.20 & 1.04 & 3.16 & 75 & 75 & 11 & 11 & 6 & $\mathrm{I}$ \\
\hline Martins et al. & 2004 & 3.73 & 1.55 & 2.18 & 59 & 58 & 7 & 9 & 4 & I\& II \\
\hline Martins et al. & 2004 & 3.66 & 0.94 & 2.72 & 75 & 74 & 7 & 9 & 4 & I \& II \\
\hline Nemcovsky et al. & 2004 & 4.60 & 0.60 & 4.00 & 87 & 87 & 40 & 40 & 12 & $1 \& \mathrm{II}$ \\
\hline Harris & 2004 & 3.80 & 0.10 & 3.70 & 97 & 97 & 25 & 39 & 49 & I\& II \\
\hline Francetti et al. & 2004 & 3.38 & 0.13 & 3.25 & 97 & 96 & 16 & 16 & 12 & I\& II \\
\hline Cetiner et al. & 2004 & 3.11 & 0.11 & 3.00 & 96 & 96 & 10 & 52 & 12 & I \& II \\
\hline Vergara, Caffesse & 2004 & 2.65 & 0.23 & 2.42 & 91 & 91 & 50 & 41 & 6 & $\mathrm{I}$ \\
\hline Vergara, Caffesse & 2004 & 3.48 & 0.49 & 2.99 & 86 & 86 & 50 & 60 & 6 & 11 \\
\hline Cheung \& Griffin & 2004 & 2.48 & 0.17 & 2.31 & 95 & 93 & 15 & 29 & 8 & I \& II \\
\hline Wilson et al. & 2005 & 3.90 & 1.40 & 2.50 & 64 & 64 & 13 & 13 & 6 & I\& II \\
\hline Burkhardt \& Lang & 2005 & 4.14 & 0.09 & 4.05 & 98 & 98 & 8 & 8 & 12 & I\& II \\
\hline Burkhardt \& Lang & 2005 & 4.19 & 0.44 & 3.75 & 90 & 89 & 8 & 8 & 12 & I \& II \\
\hline Harris et al. & 2005 & 2.90 & 0.60 & 2.30 & 80 & 79 & 21 & 41 & 3 & I\& II \\
\hline Harris et al. & 2005 & 3.20 & 0.20 & 3.00 & 96 & 94 & 21 & 39 & 3 & I \& II \\
\hline Harris et al. & 2005 & 2.90 & 0.30 & 2.60 & 91 & 90 & 21 & 38 & 3 & I \& II \\
\hline Tozum et al. & 2005 & 3.50 & 0.14 & 3.36 & 96 & 96 & 14 & 14 & 6 & I\& II \\
\hline Tozum et al. & 2005 & 3.47 & 0.97 & 2.50 & 76 & 72 & 17 & 17 & 6 & I\& II \\
\hline Hirsch et al. & 2005 & 4.90 & 0.10 & 4.80 & 98 & 98 & 65 & 169 & 24 & I\& II \\
\hline Bittencourt et al. & 2006 & 2.15 & 0.10 & 2.05 & 96 & 95 & 17 & 17 & 6 & $\mathrm{I}$ \\
\hline Moses et al. & 2006 & 4.57 & 0.70 & 3.87 & 84 & 85 & 37 & 37 & 24 & $I \& I I$ \\
\hline Chambrone et al. & 2006 & 3.89 & 0.07 & 3.82 & 98 & 98 & 14 & 34 & 6 & I\& II \\
\hline Chambrone et al. & 2006 & 3.64 & 0.21 & 3.43 & 94 & 94 & 14 & 35 & 6 & $1 \& \mathrm{II}$ \\
\hline Erley et al. & 2006 & 3.33 & 1.00 & 2.33 & 82 & 70 & 8 & 11 & 6 & I\& II \\
\hline Erley et al. & 2006 & 3.20 & 0.20 & 3.00 & 98 & 94 & 9 & 11 & 6 & I \& II \\
\hline Carvalho et al. & 2006 & 2.10 & 0.07 & 2.03 & 97 & 97 & 10 & 29 & 6 & I\& II \\
\hline Kassab et al. & 2006 & 4.00 & 0.10 & 3.90 & 98 & 98 & 10 & 10 & 6 & I \& II \\
\hline Kassab et al. & 2006 & 4.30 & 0.10 & 4.20 & 98 & 98 & 10 & 10 & 6 & I \& II \\
\hline Rahmani et al. & 2006 & 3.70 & 1.10 & 2.60 & 70 & 70 & 10 & 10 & 6 & I\& II \\
\hline Joly et al. & 2007 & 4.40 & 0.90 & 3.50 & 80 & 80 & 10 & 10 & 6 & I \& II \\
\hline Jankovic et al. & 2007 & 3.45 & 0.38 & 3.07 & 89 & 89 & 15 & 30.0 & 6.0 & I \& II \\
\hline Harris et. al. & 2007 & 3.90 & 0.20 & 3.70 & 95 & 95 & 60 & 85 & 3.0 & I\& II \\
\hline Harris et. al. & 2007 & 3.70 & 0.10 & 3.60 & 98 & 97 & 60 & 91 & 3.0 & $1 \& 11$ \\
\hline Dembowska et al. & 2007 & 2.60 & 0.10 & 2.50 & 99 & 96 & 18 & 24 & 12.0 & I\& II \\
\hline Dembowska et al. & 2007 & 3.10 & 0.30 & 2.80 & 99 & 90 & 18 & 18 & 12.0 & $1 \& 11$ \\
\hline de Souza et al. & 2008 & 3.47 & 1.48 & 1.99 & 58 & 57 & 30 & 30 & 6 & I\& II \\
\hline de Souza et al. & 2008 & 3.15 & 0.52 & 2.63 & 83 & 83 & 30 & 30 & 6 & I\& II \\
\hline
\end{tabular}




\begin{tabular}{|l|c|c|c|c|c|c|c|c|c|c|}
\hline Andia et al. & 2008 & 3.60 & 1.80 & 1.80 & 50 & 50 & 22 & 22 & 24 & I \& II \\
\hline Andia et al. & 2008 & 3.60 & 0.80 & 2.80 & 78 & 78 & 22 & 22 & 24 & I \& II \\
\hline Gunay et al. & 2008 & 4.4 & 0.4 & 4.00 & 92 & 91 & 20 & 36 & 24 & I \& II \\
\hline de Souza et al. & 2008 & 2.93 & 0.78 & 2.15 & & 73 & 7.0 & 13.0 & 12.0 & I \& II \\
\hline Han et al. & 2008 & 2.5 & 0.3 & 2.20 & 88 & 88 & 10 & 11.0 & 3.0 & I \& II \\
\hline Han et al. & 2008 & 2.7 & 0.2 & 2.50 & 93 & 93 & 10 & 14.0 & 3.0 & I \& II \\
\hline Bittencourt et al. & 2009 & 2.15 & 0.07 & 2.08 & 97 & 97 & 17 & 17.0 & 30.0 & I \\
\hline Byun et al. & 2009 & 2.45 & -0.35 & 2.80 & 98 & 114 & 20 & 10.0 & 6.0 & I \& II \\
\hline Byun et al. & 2009 & 2.53 & 0.1 & 2.43 & 89 & 96 & 20 & 10.0 & 6.0 & I \& II \\
\hline Georges et al. & 2009 & 3.76 & 0.54 & 3.22 & 85 & 86 & 35 & 68.0 & 6.0 & I \& II \\
\hline Haghighati et al. & 2009 & 3.37 & 1.06 & 2.31 & 69 & 69 & 16 & 16.0 & 6.0 & I \& II \\
\hline Cortellini et al. & 2009 & 2.7 & 0.6 & 2.10 & & 78 & 42 & 42.0 & 6.0 & I\& II \\
\hline Abolfazli et al. & 2009 & 4.83 & 0.33 & 4.5 & 93 & 93 & 12 & 12 & 6 & I \\
\hline Abundo et al. & 2009 & 3.42 & 0.17 & 3.25 & 96 & 95 & 99 & 40 & 40 & 12 \\
\hline Jhaveri et al. & 2010 & 2.8 & 0.5 & 2.3 & 83 & 82 & 96 & 10 & 10 & 6 \\
\hline Rasperini et al. & 2011 & 4.7 & 1.1 & 3.6 & 80 & 77 & 92 & 30 & 30 & 12 \\
\hline Stimmelmayr et al & 2011 & 3.2 & 0.3 & 2.90 & 93 & 91 & 98 & 10.0 & 11.0 & 6.0 \\
\hline & & & & & & & & & & \\
\hline & & & & & & & & & & \\
\hline Count & 107 & & & & & & & & & \\
\hline \multicolumn{1}{r|}{ Mean } & & 3.57 & 0.51 & 3.06 & 87 & 86 & 22.09 & 28.54 & 10.33 & \\
\hline \multicolumn{1}{c|}{} & & 0.68 & 0.43 & 0.72 & 11.18 & 11.64 & 19.21 & 28.88 & 9.40 & \\
\hline
\end{tabular}

\section{Clinical studies with CTG combined with a coronally positioned flap (CPF)}

Bouchard et al. (1994) evaluated 15 patients with 15 Miller Class I or II recession defects. CPF plus CTG procedures were performed and followed for six months. The first group of 15 patients were treated with CPF and CTG without an epithelial collar plus citric acid conditioning. The other group was treated with a CTG with an epithelial collar and no root conditioning. Mean root coverage obtained was $65 \%$ for no citric acid with epithelial collar group and $70 \%$ for citric acid without epithelial collar group. The retained epithelial collar group had a significantly greater increase in keratinized tissue width. Wennstrom and Zucchelli (1996) compared CPF plus CTG (test) with CPF alone (control) on 67 patients with 103 Miller Class I sites. Test group included 58 sites and control group included 45 sites. At the 24-month follow-up examination, the mean root coverage was $99 \%$ for the test group and $97 \%$ for the control group. Bouchard (1997) 
observed 15 patients with 15 Miller Class I or II defects over six months after utilizing a CPF with CTG technique. Citric acid or tetracycline was applied to each patient. Mean root coverage was $84 \%$ and $79 \%$ respectively. The difference was not statistically significant. Harris (2002a) reported on 266 treated defects utilizing connective tissue grafts combined with either double pedicle grafts or CPF. The mean root coverages were $97.6 \%$ and $96.1 \%$, respectively. Harris (2002b) reported on the double pedicle. laterally positioned, and CPF techniques with CTG over 27.5 months in 100 patients with 146 Miller Class I and II recession defects. His goal was to compare short and long-term results ( 13 weeks vs. 27.5 months). Mean root coverage obtained was $98.4 \%$ at 27.5 months. However, mean root coverage was $97.1 \%$ at 13 weeks, thus, supporting the concept of creeping attachment with a CTG. Butler (2003) described a new technique: the subepithelial connective tissue graft with vestibular releasing incision. The technique was developed for patients with a shallow vestibule. An envelope technique is utilized. A full thickness flap is elevated until the apical area of the root is reached. At this point, a periosteal release is made to allow for coronal placement of the flap. The mucosal tension is released with a superficial external vestibular releasing incision. Zucchelli et al. (2003) used a split mouth design in 15 Italian patients with 30 sites of either Miller Class I or II defects to compare a thick CTG and CPF placed at the CEJ to a thin CTG and CPF placed apically to the CEJ. After following patients for 12 months, they reported mean root coverage of $94.7 \%$ for thick CTGs and $97.3 \%$ for thin CTGs. Burkhardt and Lang (2005) also used a split-mouth design in studying eight patients with Miller Class I and II defects. They compared CPF with CTG using macro- (normal vision, 15 blade, 4-0 suture) versus microsurgical measures (5x loupes magnification. microblades, 7-0 
suture). Mean root coverage obtained was $90 \%$ and $98 \%$, respectively. Chambrone et al. (2006) used the CPF and CTG in 28 patients with 69 Miller Class I and II defects. The 6month study compared maxillary defects (14 patient, 34 sites) to mandibular defects (14 patients, 35 sites) and reported mean root coverage of $98 \%$ and $94 \%$, respectively. Zucchelli et al. (2010) evaluated patient morbidity and root coverage outcome after performing CTG versus de-epithelialized grafts. No differences were demonstrated in the post-operative pain. Mean root coverage obtained was $96.2 \%$ for the de-epithelialized group and $92.3 \%$ in the CTG group. Pini-Prato et al. (2010b) compared CPF with and without CTG in 13 patients using a split-mouth model. The authors judged it necessary to report 5-year (long term) data on these techniques since this information was lacking from the literature. A total or 93 Miller Class I, II and III gingival recession were treated. Mean root coverage obtained was $97 \%$ for CTG group and $94 \%$ for CPF alone. At 5 -year follow-up, a coronal displacement of the gingival margin was observed in the CPF with CTG sites, while an apical relapse was noted in the CPF without CTG.

\section{Clinical studies with CTG combined with CPF including smokers}

Erley et al. (2006) performed the CPF and CTG in 17 patients with 22 Miller Class I and II defects. The 6-month study compared the results between smokers ( 8 patient, 11 sites) and non-smokers (9 patients, 11 sites) and reported mean root coverage of $82 \%$ and $98 \%$, respectively. Andia et al. (2008) performed the CPF and CTG in 22 patients with Miller Class I and II defects. The 24-month study compared the results between smokers (11 patients, 11 sites) and non-smokers (11 patients. 11 sites) and reported mean root coverage of $50 \%$ and $78 \%$, respectively. The criteria to be considered 
smoker was $\geq 10$ cigarettes daily for $\geq 5$ years for Erley's study and $\geq 20$ cigarettes daily for $\geq 5$ years for Andia's study.

\section{Palatal Anatomy}

The palatal masticatory mucosa is widely used as a connective tissue donor site and particularly in gingival recession treatment. Great care should be taken during the harvesting procedure to avoid violating the greater palatine neurovascular bundle (GPB) due to variation in terms of size and shape of the palatal vault. Many important studies have been conducted with the objective of assessing the palatal anatomy. In a classic study on cadavers, Reiser et al. (1996) reported on the location of the GBP in relation to the height of the palatal vault. He categorized palatal vaults as being shallow $(7 \mathrm{~mm})$, average $(12 \mathrm{~mm})$ or high $(17 \mathrm{~mm})$. These measurements were taken in the premolars and molars area. Not long after Reiser's study, Monnet-Corti et al. (2006) wanted to study the maximum graft dimensions that could be taken from the palatal vault in terms of height and length in relation to the GPB. They took plaster impressions from 198 patients free of periodontal disease and took measurements from the mid-palatal aspect of the canine to the mid-palatal aspect of the second molar. The emergence of the GPB was assumed to be localized at the junction of the vertical and horizontal palatal walls of vault. The maximum height of the graft corresponded to the distances measured from the gingival margin to the marked course of the GPB of each tooth at its interproximal and midpalatal aspects. The length of the maximum available tissue graft was $31.7 \mathrm{~mm}$. The height ranged from $12.07 \mathrm{~mm}$ at the canine level to $14.7 \mathrm{~mm}$ at the mid-palatal aspect of the second molar level. Thus, in the premolar area, it was possible to harvest a CTG 
measuring $5 \mathrm{~mm}$ in height in $100 \%$ of cases and $8 \mathrm{~mm}$ in $93 \%$ of cases. Fu et al. (2011), in a cadaveric model, assessed the accuracy of predicting the location and course of the GPB on study models, compared it to the anatomic findings, and also evaluated anatomic factors that might influence the predictability. The GPB was recognized after dissection, from which the distance to the cementoenamel junction of the first molar and premolar was measured. Periodontists and residents were asked to estimate the location of the GPB on the study models. Comparisons of the estimated and true GBP position were performed. The most frequent greater palatine foramen location was between the second and third molars $(66.6 \%)$, followed by mid-palatal to second molars $(19.1 \%)$ and midpalatal to third molars $(14.3 \%)$. For most cases, there was an underestimation of the location of the GPB up to $4 \mathrm{~mm}$. Agreement on the location of the GPB was lowered with the presence of high palatal vault.

\section{Clinical studies with Coronally Positioned Flap (CPF)}

A large number of authors have reported on the use of CPFs in root coverage (Table 8). Mean root coverage was 79\% (range 34\%-98\%). Bernimoulin (1975) was the first author to report on the CPF technique. His first step was to create a new band of attached gingiva by means of a free gingival graft. He would let the graft heal for two months. The design included oblique vertical incisions, sulcular horizontal incisions that created new papilla with which the CPF would overlay. The tip of the new papilla was created a distance from the tip of the current papilla equal to the amount of recession. The papilla was then de-epithelialized, the flap reflected full-thickness to the mucogingival junction, then split to coronally position the flap at or above the cementoenamel junction. 
He performed 20 procedures on 13 patients and reported mean root coverage of $66 \%$ at 12-month evaluation. Tarnow (1986) proposed a variation of the CPF with the semilunar coronally positioned flap. The design included an apical semilunar incision to osseous following the gingival margin and extending to the base of the adjacent mesial and distal papilla. The flap is then reflected split thickness, coronally positioned at the cementoenamel junction, and held in place with pressure for five minutes. To use this procedure, an adequate width of keratinized tissue is required. Many studies have been done in attempts to describe specific elements that would increase predictability of CPF surgeries for root coverage. Allen and Miller (1989) reported on three inclusion criteria that would help in increasing CPF root coverage predictability. These criteria were: 1) Miller Class I recession, 2) $\geq 3 \mathrm{~mm}$ keratinized tissue and, 3) $\geq 1 \mathrm{~mm}$ gingival thickness. The study included 28 patients with 37 Miller Class I recession sites. Final evaluation was done at six months and mean root coverage was 98\%. Harris and Harris (1994) reported on the CPF with inlaid margins for shallow recession. They studied 18 patients with 20 Miller Class I defects and obtained mean root coverage of $99 \%$. Zucchelli and De Sanctis (2000) presented another variation of the CPF. The procedure focused on multiple adjacent recession sites in the anterior region. Oblique releasing incisions in the papilla create new papilla once the flap is rotated and coronally positioned. Sulcular incisions connected mesial and distal aspects of the flap, while a split-full-split flap was raised. The split-full-split design consisted of a split thickness papilla, full thickness gingival tissue to mucosa, and then split again to coronally position the flap. A total of 73 Miller Class I or II recession defects were treated and mean root coverage obtained was 97\%. Pini Prato et al. (1999) compared CPF with scaling and root planing (SRP) to CPF 
with root polishing in 10 patients with 10 Miller Class I and II recession defects. Mean root coverage after three months was $83 \%$ for the SRP group and $89 \%$ for the polished group. Baldi et al. (1999) reported on the relationship between tissue thickness and root coverage predictability. He studied 19 patients with 19 Miller Class I and II defects receiving a $\mathrm{CPF}$ over three months. Patients were classified as having either thin $(<0.8$ $\mathrm{mm} ; 11$ patients $)$ or thick $(\geq 0.8 \mathrm{~mm} ; 11$ patients $)$ tissue. Patients with thick tissue had $100 \%$ root coverage, while patients with thin tissue only achieved $37 \%$ mean root coverage. Pini Prato et al. (2000) studied the effect of flap tension on root coverage results. They reported on 11 patients with 22 Miller Class I defects receiving CPF over three months. Patient either received a CPF that applied tension (11 patients) or did not apply tension (11 patients) to the flap. Results showed that tension on CPF decreased root coverage. They obtained $78 \%$ mean root coverage for tension group and $87 \%$ mean root coverage for CPF without tension group. Leknes et al. (2005) performed a CPF alone on 20 subjects with 20 Miller Class I or II defects and followed the patients for six years post-operatively. Mean root coverage obtained was $98 \%$. Zucchelli and De Sanctis (2005) also completed a study using a CPF alone group in 22 patients with 73 Miller Class I recession defects. Mean root coverage obtained was $95 \%$ after a five year postoperative period. Santana et al. (2010) compared Tarnow's semilunar coronally positioned flap with CPF on 22 patients with 22 contra-lateral Miller Class I defects. Mean root coverage obtained was $87 \%$ for semilunar group and $96 \%$ for CPF group. Ozcelik et al. (2011) compared CPF alone versus CPF with orthodontic button application in 41 subjects with Miller Class I or II recessions. Six months results showed mean root coverage of $96.2 \%$ for CPF with button group and $89.1 \%$ for CPF alone group. 
Table 8

Coronally Positioned Flap

\begin{tabular}{|c|c|c|c|c|c|c|c|c|c|c|}
\hline Author & $\underline{Y r}$ & $\frac{\text { Mea }}{n}$ & Mean & Diff & $\frac{\mathrm{Rpt}}{\%}$ & $\frac{\text { Calc }}{\%}$ & \# Pts & $\stackrel{\#}{\text { Sites }}$ & Time & Miller \\
\hline & & $\underline{\text { Init }}$ & $\underline{\text { Fin }}$ & & 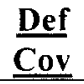 & $\underline{\mathrm{Rt}}$ & & & Mo & Class \\
\hline \multicolumn{11}{|l|}{ CPF } \\
\hline Allen, Miller & 1989 & 3.25 & 0.07 & 3.18 & 98 & 99 & 28 & 37 & 6 & $\mathrm{I}$ \\
\hline Romanos et al. & 1993 & 3.76 & 1.12 & 2.64 & 70 & 92 & 18 & 75 & 60 & NR \\
\hline Trombelli et al. & 1996 & 3.80 & 1.40 & 2.40 & 65 & 90 & 11 & 11 & 6 & I \& II \\
\hline Trombelli et al. & 1996 & 3.40 & 1.70 & 1.70 & 55 & 88 & 11 & 11 & 6 & I \& II \\
\hline $\begin{array}{l}\text { Wennstrom, } \\
\text { Zucchelli }\end{array}$ & 1996 & 4.10 & 0.20 & 3.90 & 97 & 99 & 67 & 45 & 24 & I \\
\hline Milano & 1998 & 3.27 & 0.64 & 2.63 & 84 & 95 & 11.0 & 11.0 & 12.0 & $1 \& \mathrm{II}$ \\
\hline Baldi et al. & 1999 & 3.00 & 0.60 & 2.40 & 82 & 96 & 19 & 19 & 3 & I \& II \\
\hline Pini Prato et al. & 1999 & 2.90 & 0.50 & 2.50 & 83 & 96 & 10 & 10 & 3 & I \& II \\
\hline Pini Prato et al. & 1999 & 3.10 & 0.40 & 2.60 & 89 & 97 & 10 & 10 & 3 & I \& II \\
\hline Amarante et al. & 2000 & 3.60 & 1.10 & 2.50 & 89 & 92 & 20 & 20 & 6 & I \& II \\
\hline Modica et al. & 2000 & 3.5 & 0.79 & 2.71 & 81 & 94 & 12.0 & 14.0 & 6.0 & I\& II \\
\hline Pini Prato et al. & 2000 & 2.82 & 0.64 & 2.18 & 78 & 95 & 11 & 11 & 3 & I \\
\hline Pini Prato et al. & 2000 & 2.68 & 0.36 & 2.32 & 87 & 97 & 11 & 11 & 3 & I \\
\hline Saletta et al. & 2001 & 2.77 & 0.5 & 2.27 & 82 & 96 & 33.0 & 33.0 & 3.0 & I \\
\hline Hagewald et al. & 2002 & 3.9 & 1.0 & 2.90 & 79 & 93 & 36.0 & 36.0 & 12.0 & I \& II \\
\hline Lins et al. & 2003 & 3.3 & 1.3 & 2.00 & 60 & 90 & 10 & 10 & 6 & I \& II \\
\hline Woodyard et al. & 2004 & 3.27 & 1.08 & 2.19 & 67 & 92 & 12 & 12 & 6 & $1 \& \mathrm{II}$ \\
\hline da Silva et al. & 2004 & 3.98 & 1.25 & 2.73 & 69 & 91 & 11 & 11 & 6 & 1 \\
\hline Pini Prato et al. & 2005 & 3.18 & 0.32 & 2.86 & 91 & 98 & 60 & 60 & 6 & I \\
\hline Leknes et al. & 2005 & 3.80 & 2.50 & 1.30 & 34 & 82 & 11 & 11 & 72 & I \& II \\
\hline Cortes et al. & 2004 & 3.58 & 1.08 & 2.50 & 71 & 92 & 13 & 13 & 6 & I \\
\hline Huang et al. & $2005 a$ & 2.90 & 0.50 & 2.40 & 82 & 96 & 23 & 23 & 6 & I \\
\hline $\begin{array}{l}\text { Zucchelli \& } \\
\text { DeSanctis }\end{array}$ & 2005 & 2.78 & 0.22 & 2.56 & 95 & 98 & 22 & 73 & 60 & I \& II \\
\hline Huang et al. & $2005 b$ & 2.90 & 0.50 & 2.40 & 84 & 96 & 12 & 12 & 6 & $\mathrm{I}$ \\
\hline DelPizzo et al. & 2005 & 4.13 & 0.60 & 3.53 & 87 & 96 & 15 & 15 & 24 & $I \& I I$ \\
\hline Spahr et al. & 2005 & 3.80 & 1.40 & 2.40 & 67 & 90 & 30 & 30 & 24 & I \& II \\
\hline Silva et al. & 2006 & 2.74 & 0.84 & 1.90 & 69 & 94 & 10 & 10 & 6 & 1 \\
\hline Silva et al. & 2006 & 2.54 & 0.22 & 2.32 & 91 & 98 & 10 & 10 & 6 & 1 \\
\hline $\begin{array}{l}\text { Bittencourt et } \\
\text { al. }\end{array}$ & 2006 & 2.20 & 0.21 & 1.99 & 91 & 98 & 17 & 17 & 6 & I \\
\hline $\begin{array}{l}\text { Castellanos et } \\
\text { al. }\end{array}$ & 2006 & 2.31 & 0.90 & 1.41 & 62 & 93 & 11 & 11 & 12 & I \& II \\
\hline $\begin{array}{l}\text { de Queiroz } \\
\text { Cortes et al. }\end{array}$ & 2006 & 3.58 & 1.62 & 1.96 & 56 & 88 & 13 & 13 & 24 & I \\
\hline Pilloni et al. & 2006 & 2.66 & 1.53 & 1.13 & 67 & 89 & 15 & 15 & 18 & I \& II \\
\hline
\end{tabular}




\begin{tabular}{|c|c|c|c|c|c|c|c|c|c|c|}
\hline $\begin{array}{l}\text { de Sanctis \& } \\
\text { Zucchelli }\end{array}$ & 2007 & 3.82 & 0.18 & 3.64 & 97 & 99 & 40 & 40 & 36 & I \& II \\
\hline $\begin{array}{l}\text { Bittencourt et } \\
\text { al. }\end{array}$ & 2009 & 2.20 & 0.28 & 1.92 & 89 & 98 & 17 & 17 & 30 & I \\
\hline Cortellini et al. & 2009 & 2.4 & 0.8 & 1.60 & & 94 & 43.0 & 43.0 & 6.0 & I\& II \\
\hline Aroca et al. & 2009 & 2.5 & 0.2 & 2.30 & 92 & 99 & 20.0 & 67.0 & 6.0 & I\& II \\
\hline Zucchelli et al. & 2009 & 3.64 & 0.18 & 3.46 & 95 & 99 & 11.0 & 11.0 & 6.0 & I \\
\hline Zucchelli et al. & 2009 & 3.82 & 0.64 & 3.18 & 84 & 95 & 11.0 & 11.0 & 6.0 & I \\
\hline $\begin{array}{l}\text { Cardaropoli et } \\
\text { al. }\end{array}$ & 2009 & 2.7 & 0.2 & 2.50 & 93 & 99 & 16.0 & 10.0 & 6.0 & I \& II \\
\hline Zucchelli et al. & 2009 & 2.55 & 0.22 & 2.33 & 93 & 98 & 16.0 & 45.0 & 12.0 & I\& II \\
\hline Zucchelli et al. & 2009 & 2.59 & 0.1 & 2.49 & 97 & 99 & 16.0 & 47.0 & 12.0 & I\& II \\
\hline $\begin{array}{l}\text { Banihashemrad } \\
\text { et al. }\end{array}$ & 2009 & 3.64 & 1.64 & 2.00 & 57 & 88 & 7.0 & 11.0 & 6.0 & I\& II \\
\hline Santana et al. & 2010 & 3.20 & 0.11 & 3.09 & 97 & 97 & 18 & 18 & 6 & \\
\hline Count & 43 & & & & & & & & & \\
\hline Mean & & 3.18 & 0.74 & 2.44 & 80 & 78 & 19.02 & 23.72 & 13.53 & \\
\hline sd & & 0.55 & 0.56 & 0.60 & 14.72 & 15.70 & 13.09 & 18.65 & 16.11 & \\
\hline
\end{tabular}

\section{Clinical studies with CPF including smokers}

Silva et al. (2006) observed the importance of smoking status on the effects of the CPF. Their study divided 20 Miller Class I patients into two groups: current smokers $\geq$ 10 cigarettes/ day for past 5 years; 10 patients) and non-smokers (never smokers; 10 patients). After a six month follow-up period mean root coverage obtained for smokers was $69 \%$ versus $91 \%$ for non-smokers. Smoking had a negative effect on the CPF root coverage technique.

Mean root coverage for the CPF procedures is $79 \%$ (range $34-98 \%$; Table 8 ). CTG procedures produce a significantly better result with $87 \%$ mean root coverage (range 57\%-98\%).

\section{Clinical studies with Acellular Dermal Matrix Allograft (Alloderm ${ }^{\circledR}$ )}

Since its introduction to dentistry in 1994 , Alloderm $\circledast$ has been widely accepted 
for soft tissue applications. Dodge et al. (1998) was among the first to study acellular dermal matrix allograft (Alloderm $\left.{ }^{\circledR}\right)$ and its effect on root coverage in conjunction with a Bernimoulin (1975) CPF. Six patients with 18 recession sites were treated with Alloderm ${ }^{\circledR}$ and a CPF. Mean root coverage obtained was $96 \%$ at 10 weeks. Henderson et al. (2001) also examined the use of Alloderm ${ }^{\circledR}$ and a CPF in root coverage surgery. The study focused on Alloderm ${ }^{\circledR}$ 's characteristic basement membrane on one side of the graft and connective tissue on the other side. Twenty patients with 20 Miller Class I and II recession sites were given an Alloderm ${ }^{\circledR}$ graft in conjunction with a CPF in attempts to correct recession defects. The effects of the Alloderm ${ }^{\circledR}$ basement membrane placement (facing osseous or flap) were evaluated. After a 12-month follow-up period, they found mean root coverage of $95 \%$. No statistical difference was seen between the two groups. Paolantonio et al. (2002) studied 15 patients with 15 Miller Class I and II recession sites. Patients received Alloderm® in combination with a CPF and were followed for 12 months post-operatively. They reported mean root coverage of $83 \%$. Woodyard et al. (2004) used a combination of Alloderm ${ }^{\circledR}$ and a CPF in a study of 12 patients with 12 Miller Class I and II defects and obtained a mean root coverage of $99 \%$ after 6 months. Hirsh et al. (2005) conducted a similar but longer study using Alloderm ${ }^{\circledR}$ and a CPF in 101 patients with 262 Miller Class I and II recession sites. The follow-up period lasted 24 months and mean root coverage obtained was $96 \%$. Harris $(2000,2002 \mathrm{c}, 2004)$ also performed studies with longer post-operative follow-ups evaluating root coverage results of Alloderm ${ }^{\circledR}$ combined with CPF. The first two Harris studies $(2000,2002 \mathrm{c})$ utilized Alloderm ${ }^{\circledR}$ with a CPF and followed patients for three and 19 months, respectively. Mean root coverage obtained for the three month study was $96 \%$ and $87 \%$ for the 19 
month study. Harris (2004) observed 25 patients with 57 Miller Class I and II recession sites over 49 months after they received Alloderm ${ }^{\circledR}$ with a CPF. Mean root coverage obtained was $66 \%$. Recently, in a course manual, E.P. Allen described the coronally positioned tunnel technique, a modification of the supraperiosteal envelope technique developed in by Allen (1994). The coronally positioned tunnel is accomplished by a microsurgical approach to achieve a split-thickness dissection that frees up the gingiva and mucosa. The papilla is left intact without any incisions, but is lifted off the interproximal septum to facilitate coronal positioning. Papageorgakopoulos et al. (2008) compared the coronally positioned tunnel (CPT) to a coronally positioned flap using Alloderm ${ }^{\circledR}$. They reported $95 \%$ defect coverage for the CPF versus $78 \%$ for the CPT. Shepherd et al. (2009) compared the CPT plus Alloderm® to that of a CPT plus Alloderm ${ }^{\circledR}$ and platelet-rich plasma. They reported $90 \%$ defect coverage with the platelet-rich plasma group versus $70 \%$ defect coverage with the CPT/Alloderm® group. Mean root coverage obtained from the studies using Alloderm® was $81 \%$ (range 50 $99 \%$; Table 9).

Table 9

Acellular Dermal Matrix Allograft (Alloderm $(\mathbb{R})$

\begin{tabular}{|c|c|c|c|c|c|c|c|c|c|c|}
\hline Author & Year & Mean & Mean & Diff & $\frac{\text { Rpt }}{\%}$ & $\frac{\text { Calc }}{\frac{1}{\%}}$ & \# Pts & $\stackrel{\#}{\stackrel{\#}{\text { Sites }}}$ & Time & Miller \\
\hline & & $\overline{\frac{\text { Init }}{\operatorname{Rec}}}$ & $\overline{\frac{\text { Fin }}{\operatorname{Rec}}}$ & & $\frac{\overline{D e f}}{\mathrm{Cov}}$ & $\underline{\overline{\mathrm{Rt}}}$ & & & Mo & Class \\
\hline & & & & & & & & & & \\
\hline \multicolumn{11}{|l|}{ Alloderm } \\
\hline Harris & 2000 & 3.10 & 0.20 & 2.90 & 96 & 99 & 25 & 65 & 3 & $I \& I I$ \\
\hline $\begin{array}{l}\text { Aichelmann- } \\
\text { Reidy et al. }\end{array}$ & 2001 & 2.50 & 0.80 & 1.70 & 66 & 94 & 22 & 22 & 6 & I \& II \\
\hline Henderson et al. & 2001 & 4.20 & 0.25 & 3.95 & 95 & 98 & 10 & 10 & 12 & I\& II \\
\hline Henderson et al. & 2001 & 3.70 & 0.15 & 3.55 & 95 & 99 & 10 & 10 & 12 & I \& II \\
\hline Novaes et al. & 2001 & 3.23 & 1.13 & 2.10 & 67 & 92 & 9 & 9 & 6 & I \& II \\
\hline Harris & $2002 c$ & 3.10 & 0.40 & 2.70 & 87 & 97 & 20 & 47 & 19 & I\& II \\
\hline $\begin{array}{l}\text { Paolantonio et } \\
\text { al. }\end{array}$ & 2002 & 4.75 & 0.73 & 4.02 & 83 & 95 & 15 & 15 & 12 & I \& II \\
\hline Tal et al. & 2002 & 5.14 & 0.57 & 4.57 & 89 & 96 & 7 & 7 & 12 & I\& II \\
\hline
\end{tabular}




\begin{tabular}{|c|c|c|c|c|c|c|c|c|c|c|}
\hline Woodyard et al. & 2004 & 3.46 & 0.04 & 3.42 & 99 & 100 & 12 & 12 & 6 & I\& II \\
\hline Harris & 2004 & 3.20 & 1.10 & 2.10 & 66 & 92 & 25 & 57 & 49 & I\& II \\
\hline Barros et al. & 2004 & 3.40 & 1.30 & 2.10 & 64 & 90 & 14 & 32 & 6 & I \& II \\
\hline Barros et al. & 2004 & 3.90 & 0.90 & 3.00 & 79 & 93 & 14 & 32 & 6 & $I \& I I$ \\
\hline Cortes et al. & 2004 & 3.46 & 0.88 & 2.58 & 76 & 94 & 13 & 13 & 6 & $\mathrm{I}$ \\
\hline Mehlbauer & 2005 & 3.64 & 0.14 & 3.50 & 96 & 99 & 7 & 7 & 12 & I\& II \\
\hline Mehlbauer & 2005 & 3.57 & 0.07 & 3.50 & 98 & 99 & 7 & 7 & 12 & $1 \& \mathrm{II}$ \\
\hline Santos et al. & 2005 & 2.58 & 0.62 & 1.96 & 74 & 95 & 12 & 26 & 12 & $I \& I I$ \\
\hline Hirsch et al. & 2005 & 4.20 & 0.20 & 4.00 & 96 & 99 & 101 & 262 & 24 & I\& II \\
\hline $\begin{array}{l}\text { de Queiroz } \\
\text { Cortes et al. }\end{array}$ & 2006 & 3.46 & 1.15 & 2.31 & 68 & 92 & 13 & 13 & 24 & I \\
\hline Rahmani et al. & 2006 & 4.05 & 1.15 & 2.90 & 72 & 92 & 10 & 10 & 6 & $I \& I I$ \\
\hline $\begin{array}{l}\text { Papageorgakopo } \\
\text { ulos }\end{array}$ & 2008 & 3.40 & 0.17 & 3.23 & 95 & 99 & 12 & 12 & 4 & I \& II \\
\hline $\begin{array}{l}\text { Papageorgakopo } \\
\text { ulos }\end{array}$ & 2008 & 3.10 & 0.67 & 2.44 & 78 & 95 & 12 & 12 & 4 & I\& II \\
\hline Joly et al. & 2007 & 4.20 & 2.10 & 2.10 & 50 & 85 & 10 & 10 & 6 & $I \& \mathrm{II}$ \\
\hline Felipe et al. & 2007 & 2.88 & 0.79 & 2.09 & 69 & 94 & 10 & 10 & 6 & I\& II \\
\hline Felipe et al. & 2007 & 2.73 & 0.41 & 2.32 & 85 & 97 & 10 & 10 & 6 & $I \& \mathrm{II}$ \\
\hline Andrade et al. & 2008 & 2.88 & 0.72 & 2.16 & 74 & 95 & 15 & 30 & 12 & I\& II \\
\hline Andrade et al. & 2008 & 2.73 & 0.46 & 2.27 & 83 & 97 & 15 & 30 & 12 & I\& II \\
\hline Haghighati et al. & 2009 & 2.93 & 0.41 & 2.52 & 85 & 97 & 16 & 16.0 & 6.0 & I\& II \\
\hline de Souza et al. & 2008 & 3.15 & 1.15 & 2.00 & & 92 & 7.0 & 13.0 & 12.0 & $I \& \mathrm{II}$ \\
\hline Shepherd et al. & 2009 & 3.6 & 1.0 & 2.60 & 70 & 93 & 9.0 & 9.0 & 4.0 & $I \& \mathrm{II}$ \\
\hline Count & 29 & & & & & & & & & \\
\hline Mean & & 3.46 & 0.68 & 2.78 & 81 & 95 & 15.93 & 27.86 & 10.92 & \\
\hline sd & & 0.63 & 0.47 & 0.76 & 13.02 & 3.46 & 17.08 & 47.49 & 9.13 & \\
\hline
\end{tabular}

\section{Histology of CTG}

Histology taken from CTGs used for root coverage vary from long junctional epithelium to regeneration (new bone, cementum, and connective tissue attachment to tooth). Harris (1999a) conducted studies that found both long junctional epithelium and regeneration. The first study was a case report on a CTG with a double pedicle flap. The patient was followed for six months, after which time two teeth were extracted for prosthetic purposes and processed for histology. Results for one tooth revealed a long junctional epithelium while the other revealed repair (connective tissue adjacent to the tooth intermixed with epithelium). However, no new bone or cementum was seen in either tooth. In a second case report using a CTG with a double pedicle flap, Harris 
(1999b) followed the patient for five months, after which the tooth had to be extracted due to a vertical root fracture and histology was taken. Results from one tooth revealed areas of regeneration. Bruno and Bowers (2000) also looked at the histologic attachment of soft tissue following root coverage with a CTG in a case report of one tooth. After a 12-month follow-up timeframe the majority of area of the covered defect showed connective tissue adhesion with fibers running parallel to the root. The connective tissue was highly vascularized. Goldstein et al. (2001) found regeneration in a case study he completed. A CTG was used for root coverage on a 27-year old female who was having her maxillary first premolar removed for orthodontic purposes. Fourteen months postsurgery the teeth were extracted and analyzed histologically. New connective tissue attachment and cementum were found. In a case report of a 24 -year old needing a CTG for root coverage, Majzoub et al. (2001) evaluated histologic results 12 months postsurgically when teeth were extracted for orthodontic purposes. Healing largely revealed long junctional epithelium over the previously recessed site with minimal areas of new cementum in the apical region. No resorption nor ankylosis was present in any of the serial sections. Carnio et al. (2003) also reported the histology of a CTG used for root coverage in a case report. Two years after grafting, the tooth was extracted and histologic results revealed areas of dentinal resorption and formation of new bone in the deepest area of active resorption. Cummings et al. (2005) evaluated histologic differences in CTG or $\mathrm{ADM}$ with a CPF versus a CPF alone in four patients previously treatment planned for multiple extractions. Six months post-operatively the CTG and ADM showed areas of new cementum formation and unchanged osseous architecture. CTG revealed connective tissue fibers running parallel the root surface. The ADM showed new fibroblasts, 
vascularity and collagen components. In an in vivo case report, Roman et al. (2010) reported on a new method, using a bone marrow biopsy needle. Two patients with gingival recessions were treated with $\mathrm{CPF}$ with $\mathrm{CTG}$ and the histological results were observed. The histological findings revealed dense grafted tissues but no ligament or bone were observed. This indicated that the healing was a long connective tissue attachment.

The above mentioned studies examined human histology, no animal studies were evaluated. Controversy still exists as to whether soft tissue healing results in true regeneration. Many histologic studies are still needed to confirm or deny the concept that root coverage results in regeneration.

\section{Histology of CPF}

Gottlow et al. (1986) examined histology of the CPF in beagle dogs. Buccal recession was surgically created and notches made in the roots at the level of the gingival margin. Full thickness flaps were raised and coronally positioned. Three months postoperatively the dogs were sacrificed and the jaws sectioned for histologic evaluation. New connective tissue attachment was seen inserting into the root, with accompanying new cementum and osseous formation. Cummings et al. (2005), as mentioned above, reported histology in humans receiving CPFs which showed connective tissue fibers that were arranged parallel to the root surface rather than perpendicular. Elastin fibers were interspersed throughout the connective tissue and the osseous height was unchanged by the CPF. 


\section{Histology of Alloderm ${ }^{\circledR}$}

In a case report, Harris (1998b) examined the histology of Alloderm ${ }^{\circledR}$ used in root coverage in combination with a CPF. Histology revealed the Alloderm ${ }^{\circledR}$ had similar characteristics as the CTG used in another area of the mouth. Verhoeff's staining showed complete incorporation of the Alloderm ${ }^{\circledR}$ into the connective tissue. Harris (2001) used Alloderm ${ }^{\circledR}$ around implants in an attempt to increase the width of keratinized tissue. Histologic evaluation revealed a differentiation between the Alloderm ${ }^{\circledR}$ and connective tissue. Cummings et al. (2005) compared CTG and Alloderm® with a CPF in teeth previously treatment planned for extraction. Histologic findings revealed no differentiation between either CTG or Alloderm ${ }^{\circledR}$ graft and the recipient connective tissue bed. However, original Alloderm ${ }^{\circledR}$ elastin fibers were noted. New fibroblasts and vascular components were seen in the Alloderm ${ }^{\circledR}$. Alloderm ${ }^{\circledR}$ and CTG also exhibited new cementum formation plus a combination of long junctional epithelium and connective tissue adhesion (connective tissue fibers were arranged parallel to the root). The alveolar crest was unchanged from the baseline height.

\section{Creeping Attachment}

Goldman (1964) was the first to define the concept of creeping attachment in root coverage. Creeping attachment was defined as any coronal migration of the gingival margin following root coverage surgery, usually occurring one month to one year postoperatively. Thereafter, Ward (1974) reported on creeping attachment over the course of six months in 18 case reports. A frenectomy combined with a free gingival graft was used to increase the width of keratinized tissue. He found a creeping attachment of $0.74 \mathrm{~mm}$ 
$(24 \%)$ at the final measurement. Matter (1980) studied free gingival grafts on ten patients over the course of 10 years with recession defects $<3 \mathrm{~mm}$. He also differentiated between bridging, initial root coverage, and creeping attachment. Mean coverage obtained was $67 \%$ (10\% bridging, $57 \%$ creeping attachment). No change was seen between one and five years, supporting the concept that creeping attachment occurs between one month and one year post-operatively. Nelson (1987) treated 29 teeth with gingival recession in 14 patients with a CTG and pedicle flap. Patients were followed for 42 months. Mean root coverage obtained was $88 \%$ and some areas revealed a gain of $1-2 \mathrm{~mm}$ over the first year. Harris (1997) also studied creeping attachment in CTGs combined with a double pedicle flap. Nineteen patients with 22 recession sites were treated and followed for 12 months post-operatively. Mean root coverage obtained was $97.1 \%$ with mean creeping attachment of $0.8 \mathrm{~mm}$. Evidence of creeping attachment was found in $21 / 22$ defects $(95.5 \%)$ and $18 / 19$ patients $(94.7 \%)$. Creeping attachment contributed to complete root coverage in $17 / 22$ defects $(77.3 \%)$ and $15 / 19$ patients $(78.9 \%)$. In another study utilizing a CTG. Harris et al. (2005) combined a CTG with either a double pedicle, coronally positioned, or lateral sliding flap. One hundred forty six Miller Class I and II recession sites in 100 patients were evaluated for short-term (13 weeks) and long-term (27.5 months) results. Mean root coverage obtained at 13 weeks was $97.1 \%$ and increased to $98.4 \%$ at 27.5 months. This study demonstrated that mean amounts of root coverage do not decrease but tend to improve with time when using the connective tissue graft.

\section{The significance of tissue thickness in root coverage procedures}

In a classic CPF study, Allen and Miller (1989) specified that at least $1 \mathrm{~mm}$ 
gingival thickness should be present to increase root coverage predictability. They were among the first authors to include gingival thickness in their selection criteria. Harris (1997) also acknowledged the impact that gingival thickness had on root coverage predictability. He compared CTG/double pedicle versus GTR. Subjects were subdivided into two groups: thick or thin tissue. Tissue thickness in subjects treated with the CTG did not have a significance effect on the outcome. However, mean root coverage obtained for patients with thin tissue in the GTR group was $26.7 \%$ and $95.9 \%$ for patients with thick tissue. Baldi et al. (1999) evaluated the impact of flap thickness on root coverage results in 19 patients with 19 recession defects $\geq 2 \mathrm{~mm}$ treated with a CPF. Flaps with a thickness $\geq 0.8 \mathrm{~mm}$ had $100 \%$ root coverage. Flaps with $<0.8 \mathrm{~mm}$ thickness resulted in only partial root coverage. Huang et al. (2005b) studied factors affecting the outcomes of CPF procedures. Twenty-three patients each with Miller's Class I recession defect were included. Analysis revealed that an initial gingival thickness $\geq 1.2 \mathrm{~mm}$ was associated with complete root coverage at the 6-month follow-up. The results of these studies indicate that there is a direct relationship between flap thickness and recession reduction. 


\section{CHAPTER II}

\section{METHODS}

Study Design. Twenty-four patients with at least 1 site with Miller Class I or II recession defect $\geq 3 \mathrm{~mm}$ received root coverage surgery and were followed for a period of 4 months. Twelve patients in the positive control group were treated with a coronally positioned tunnel and a connective tissue graft. The test group consisted of 12 patients who were treated with a coronally positioned tunnel and Alloderm®. The surgical technique for both the control and test groups was based on the coronally positioned tunnel procedure described by Allen (E. P. Allen, Center for Advanced Dental Education, Dallas, TX; course manual). Sutures used for both test and control groups were resorbable Maxon 5-0, 3/8 circle $13 \mathrm{~mm}$ needle for the allograft and PTFE 4-0, 3/8 circle $13.1 \mathrm{~mm}$ needle for the soft tissue. Patients were randomly assigned to the connective tissue graft or acellular dermal matrix allograft group using a coin toss. All surgical procedures were completed by one operator (EG) under the direction of one mentor (HG). The surgeon was trained in the procedures until considered proficient. All measurements were performed by the blinded examiner (VK). The mentor performed the coin toss and verified the measurements taken by the blinded examiner. The treatment was not revealed to the blinded examiner. All patients signed an informed consent approved by the University of Louisville Institutional Review Board. The study was 
conducted between January 1, 2011 and August 31, 2011 in the Graduate Periodontics clinic at the University of Louisville.

Inclusion Criteria. Inclusion criteria were: 1) at least one Miller Class I or II recession defect $\geq 3 \mathrm{~mm}$ (Miller 1985) on a non-molar tooth; 2) the patient must be between 18 and 90 years of age.

Exclusion Criteria. Exclusion criteria were: 1) debilitating systemic or infectious diseases (HIV or hepatitis) or any diseases that affect the periodontium; 2) a known allergy to any of the materials used in the study; 3) requirement for antibiotic prophylaxis; 4) CEJ not identifiable; 5) a root surface restoration at the recession site; 6) failure to maintain an oral hygiene level of at least $80 \%$ plaque free surfaces; 7) pregnancy or lactation; 8) use of tobacco products through smoking or a smokeless tobacco habit; 9) alcohol abuse problems; 10) long-term steroid therapy; 11) history of a previous root coverage procedure, graft or GTR involving the recession site; 12) failure to complete the informed consent.

Pre-surgical Treatment. Each patient received a full diagnostic work-up including periapical and bite-wing radiographs of the recession site, study casts, intraoral photographs, and a full mouth clinical examination to record clinical attachment level, probing depth, recession, keratinized tissue width, and tooth mobility. All women of childbearing age received a pregnancy test. Detailed oral hygiene instructions were provided.

Baseline data included the following: 1) Miller classification of the recession defects (Miller 1985, Appendix C); 2) Plaque index (Silness and Loe 1964, Appendix D); 3) Gingival index (Lobene 1986, Appendix E); 4) Bleeding on probing using 
dichotomous scoring (Appendix F); 5) Gingival margin levels (Recession) measured from the CEJ to the gingival margin; 6) Keratinized tissue measured from the gingival margin to the mucogingival junction (Appendix G); 7) Clinical attachment level measured from the CEJ to the bottom of the clinical periodontal pocket; 8) Tooth mobility measured using a modification of the Miller's index (Laster et al. 1975, Appendix H); 9) Creeping attachment measured from the CEJ to the gingival margin starting at 8 weeks post-surgery until the 4-month final examination (Appendix I); 10) Tooth vitality tested using an electric pulp tester and a cold test; 11) Radiographic examination utilizing a paralleling technique included a pre-operative periapical and bitewing x-ray; 12) Patient models; 13) Clinical photographs.

Surgical Treatment. Pre-surgical measurements were made prior to determining the treatment modality (Appendix A). Probing depth, keratinized tissue width, and gingival margin level was measured prior to anesthesia. The soft tissue recession defect was also measured horizontally and vertically at the level of the CEJ and $1 \mathrm{~mm}$ coronal to the gingival margin. Following administration of local anesthesia, and reflection of the tunnel, the distance from the $\mathrm{CEJ}$ to the alveolar crest was measured at the mid-facial and at the mesial and distal interproximal. Defect width was measured horizontally at the level of the interproximal osseous crest level and $1.0 \mathrm{~mm}$ coronal to the defect base (Appendix B). Prior to the incisons, the root surface was meticulously root planed using ultrasonic and hand instruments to obtain a smooth, hard root surface.

Sites were treated with a coronally positioned tunnel procedure without any vertical releasing incisions (E. P. Allen, Center for Advanced Dental Education, Dallas, TX; course manual). The tissue was elevated using a split thickness technique beyond the 
mucogingival junction and extended apically until enough release was obtained to permit adequate coronal positioning. The tunnel was extended at least one tooth mesial and distal to the recession site. Interproximal papilla were elevated off the interproximal septum, for both the facial and lingual, to facilitate coronal positioning. The connective tissue graft was harvested from the palate using the trap door technique. The Alloderm® or the connective tissue graft was positioned at the CEJ and extended approximately 3 $\mathrm{mm}$ beyond the osseous defect margins. A continuous sling suture was used to secure the graft (Maxon, Kendall Healthcare, Mansfield, MA 02048). The flap margin was positioned as coronal to the CEJ as possible to completely cover the defect and the graft. The flap was sutured using a continuous line angle sling suture (PTFE, Osteogenics Biomedical, Lubbock, TX, 79424). Any papillae that was incised during the surgery was closed with an interrupted suture.

Post-operative instructions were given along with the following prescriptions: 1) systemic doxycycline hyclate $100 \mathrm{mg}$ once a day for 14 days; 2) naproxen $375 \mathrm{mg}$ q12h for 7 days; 3) Vicodin ES® q6-8h prn pain; and 4) Medrol ${ }^{\circledR}$ dose pack of 21 tablets of 4 mg methylprednisolone; 6 tablets on day 1,5 on day 2 , decrease by 1 per day until the last 1 tablet dose on day 6 .

Post-Surgical Management. All patients were seen weekly for 2 weeks, then every two weeks until 8 weeks post-operatively, and then every two months until the end of the study period (4 months). Suture removal took place between 4-8 weeks postoperatively. Post-operative visits consisted of supragingival plaque removal and oral reinforcement. 
Eight weeks post-operatively was considered the baseline for the measurement of creeping attachment. Creeping attachment was measured at 2 months and at the 4-month final examination (see Appendix I).

Visual Analog Scale of Pain and Esthetic Outcomes. Assessment of pain was made at 1-2 week and 8 week post-operatively using the visual analog scale. Assessment of esthetic was made 4-month post-operatively using the visual analog scale.

Four-Month Evaluation. At the end of the 4-month evaluation period all baseline clinical measurements were repeated.

Calibration. All measurements were made with a $15 \mathrm{~mm}$ North Carolina probe by a blinded examiner. Intra-examiner reliability was established by at least 2 exams on 3 patients to achieve $70 \%$ exact measurements and $90 \%$ of measurements within $1.0 \mathrm{~mm}$.

Statistical Analysis. Means and standard deviations were calculated for all parameters. A paired t-test was used to evaluate the statistical significance of the differences between initial and final data. An unpaired t-test was used to evaluate statistical differences between the test and control groups. The sample size of 12 per group gave $90 \%$ statistical power to detect a difference of $1 \mathrm{~mm}$ defect coverage between groups. Power calculations were based on data from previous studies. 


\section{CHAPTER III}

\section{RESULTS}

A total of 9 females and 3 males with a mean age of $38 \pm 12$, ranging from 22 to 55 , were enrolled in the ADM group while 7 females and 5 males with a mean age of 38 \pm 16 , ranging from 23 to 67 , were enrolled in the CT group. The ADM group consisted of 1 maxillary central incisor, 7 maxillary canines, 1 mandibular lateral incisor and 3 mandibular premolars. The CT group consisted of 4 maxillary canines, 4 mandibular central incisors, and 4 mandibular premolars. There were no smokers enrolled in either group.

Clinical Indices. The mean Plaque Index (Silness and Loe 1964) was initially low and slightly decreased by 4 months for both the CT and ADM groups. For both groups, the difference from initial to 4-month values was not significant $(p>0.05$, Table 11). There were no statistically significant differences between groups $(p>0.05)$. The mean Gingival index (Lobene 1986) was initially low for both groups and did not significantly change at 4 months ( $p>0.05$, Table 11). There were no statistically significant differences between groups $(p>0.05)$. There was minimal bleeding on probing at the initial and the 4-month time point. Mobility (Laster et al. 1975) was low initially and at 4 months for both the CT and the ADM groups ( $p>0.05)$. There were no statistically significant differences between groups $(p>0.05)$. 
Probing Measurements. Mean probing depth was $1.4 \pm 0.4 \mathrm{~mm}$ initially for the $\mathrm{ADM}$ group and $2.0 \pm 0.5 \mathrm{~mm}$ for the $\mathrm{CT}$ groups. At 4 months, the measurements did not significantly change in both groups $(\mathrm{p}>0.05)$. There were no statistically significant differences between groups ( $p>0.05$, Table 12). The mean clinical attachment level was 4.0 to $4.5 \mathrm{~mm}$ initially but improved significantly by time $4(\mathrm{p}<0.05)$ due to the amount of defect coverage. There were no statistically significant differences between groups ( $p$ $>0.05$ ). Mean keratinized tissue was initially $1.8 \pm 1.0 \mathrm{~mm}$ for the ADM group and $0.8 \pm$ $0.8 \mathrm{~mm}$ for the CT group and there was minimal change for both groups $(\mathrm{p}>0.05$, Table 12). There were no statistically significant differences between groups $(\mathrm{p}>0.05)$.

Creeping Attachment. Creeping attachment, or the mean recession change from 2 to 4 months in this study, showed a decrease in recession of approximately $0.1 \pm 0.3$ $\mathrm{mm}$ for the ADM group and $0.2 \pm 0.4 \mathrm{~mm}$ for the CT group $(\mathrm{p}>0.05)$. There were no statistically significant differences between groups $(p>0.05$, Table 13).

Osseous Dehiscence. The mean facial dehiscence defect depth at the initial exam was approximately $5.7 \mathrm{~mm}$ for the ADM group and $5.5 \mathrm{~mm}$ for the CT group $(\mathrm{p}<0.05$. Table 14). The difference between recession depth and the dehiscence depth was $2.6 \pm$ $0.7 \mathrm{~mm}$ for the ADM group and $2.4 \pm 0.7 \mathrm{~mm}$ for the CT group.

Gingival Recession. The mean facial recession defect at the initial exam for the ADM group was $3.1 \pm 0.3 \mathrm{~mm}$ which was reduced to $0.1 \pm 0.3 \mathrm{~mm}$ at 4 months for defect coverage of $3.0 \pm 0.4 \mathrm{~mm}$ or $97 \%(\mathrm{p}<0.05$, Table 15$)$. For the CT group, mean initial recession was $3.0 \pm 0.1 \mathrm{~mm}$ which was reduced to $0.2 \pm 0.6 \mathrm{~mm}$ at 4 months for defect coverage of $2.8 \pm 0.4 \mathrm{~mm}$ or $95 \%(\mathrm{p}<0.05$, Table 16). Mean root coverage, or the percentage of the root that was covered, rather than the recession defect, was $99 \%$ for 
both group. Frequency data indicated that the predictability of obtaining $\geq 90 \%$ defect coverage was $92 \%$ or 11 of 12 sites for both groups (Tables 15 and 16 ).

Visual Analog Scale of Pain and Esthetic Outcomes (VAS). Regarding the surgical grafting site the mean VAS score for the CT group was $22 \pm 18 \mathrm{~mm}$ at $1-2$ week and $15 \pm 21 \mathrm{~mm}$ at 8 weeks post-operatively. The mean VAS score for the ADM group was $20 \pm 20 \mathrm{~mm}$ at $1-2$ week and $10 \pm 10 \mathrm{~mm}$ at 8 week post-operatively. For the CT group, the VAS at harvest site was $35 \pm 32 \mathrm{~mm}$ at $1-2$ week and $25 \pm 30 \mathrm{~mm}$ at 8 week post-operatively. The esthetic 4-month VAS score was $94 \pm 9 \mathrm{~mm}$ for the CT group and $97 \pm 5 \mathrm{~mm}$ for the ADM group. 
Table 10

Clinical Indices for Test and Control Sites

Mean \pm sd

\begin{tabular}{|cccccc|}
\hline & & n & Initial & 4 Month & Change \\
\hline \hline Plaque & ADM & 12 & $0.3 \pm 0.4$ & $0.2 \pm 0.3$ & $0.1 \pm 0.5$ \\
Index & CT & 12 & $0.6 \pm 0.3$ & $0.5 \pm 0.5$ & $0.0 \pm 0.6$ \\
\hline $\begin{array}{c}\text { Gingival } \\
\text { Index }\end{array}$ & ADM & 12 & $0.1 \pm 0.2$ & $0.1 \pm 0.3$ & $0.0 \pm 0.1$ \\
\hline $\begin{array}{c}\text { Bleeding } \\
\text { Probing }\end{array}$ & ADM & 12 & $0.2 \pm 0.2$ & $0.3 \pm 0.5$ & $0.1 \pm 0.4$ \\
\hline CT & 12 & $0.0 \pm 0.1$ & $0.1 \pm 0.1$ & $0.1 \pm 0.2$ \\
\hline $\begin{array}{c}\text { Mobility } \\
\text { A2 }\end{array}$ & CDM & 12 & $0.1 \pm 0.2$ & $0.0 \pm 0.1$ & $0.1 \pm 0.2$ \\
\hline
\end{tabular}

$\mathrm{ADM}=$ Acellular dermal matrix allograft, test group

$\mathrm{CT}=$ Connective tissue autograft, positive control group 
Table 11

Probing Measurements for Test and Control Sites

Mean $\pm \mathrm{sd}(\mathrm{mm})$

\begin{tabular}{|cccccc|}
\hline & & n & Initial & 4 Month & Change \\
\hline \hline Probing & ADM & 12 & $1.4 \pm 0.4$ & $1.5 \pm 0.3$ & $0.1 \pm 0.4$ \\
\hline $\begin{array}{c}\text { Depth } \\
\begin{array}{c}\text { Attachment } \\
\text { Level }\end{array}\end{array}$ & CT & 12 & $2.0 \pm 0.5$ & $2.1 \pm 0.8$ & $0.1 \pm 0.6$ \\
\hline $\begin{array}{c}\text { Keratinized } \\
\text { ADM }\end{array}$ & 12 & $4.5 \pm 0.4$ & $1.5 \pm 0.5$ & $3.0 \pm 0.6^{*}$ \\
Tissue & CT & 12 & $4.1 \pm 0.2$ & $1.3 \pm 0.6$ & $2.9 \pm 0.5^{*}$ \\
\hline
\end{tabular}

* $=\mathrm{p}<0.05$ between initial and 4-month values

$\mathrm{ADM}=$ Acellular dermal matrix allograft, test group

$\mathrm{CT}=$ Connective tissue autograft, positive control group 


\section{Table 12}

Creeping Attachment Mid-buccal

Mean $\pm \mathrm{sd}(\mathrm{mm})$

\begin{tabular}{|cccccc|}
\hline & & n & 2 Month & 4 Month & Change \\
\hline Creeping & ADM & 12 & $0.2 \pm 0.4$ & $0.1 \pm 0.3$ & $0.1 \pm 0.3$ \\
Attachment & CT & 12 & $0.4 \pm 0.7$ & $0.2 \pm 0.6$ & $0.2 \pm 0.4$
\end{tabular}

ADM = Acellular dermal matrix allograft, test group

$\mathrm{CT}=$ Connective tissue autograft, positive control group 
Table 13

Recession depth vs. dehiscence depth

Mean $\pm \mathrm{sd}(\mathrm{mm})$

\begin{tabular}{|cccccc|}
\hline & & n & Dehiscence & Recession & Difference \\
\hline \hline $\begin{array}{c}\text { Dehiscence } \\
\text { Depth } \\
\text { vs. }\end{array}$ & ADM & 12 & $5.7 \pm 0.8$ & $3.1 \pm 0.3$ & $2.6 \pm 0.7$ \\
$\begin{array}{c}\text { Recession } \\
\text { Depth }\end{array}$ & CT & 12 & $5.5 \pm 0.7$ & $3.0 \pm 0.1$ & $2.4 \pm 0.7$ \\
\hline
\end{tabular}

$\mathrm{ADM}=$ Acellular dermal matrix allograft, test group

$\mathrm{CT}=$ Connective tissue autograft, positive control group 
Table 14

Recession, defect coverage, root coverage for test teeth treated with the tunnel procedure and acellular dermal matrix.

\begin{tabular}{|c|c|c|c|c|c|c|c|c|c|}
\hline \multicolumn{3}{|c|}{ Patient Data } & \multicolumn{3}{|c|}{ Recession Data } & \multicolumn{2}{|c|}{ Defect Coverage } & \multicolumn{2}{|c|}{ Defect Elimination } \\
\hline & & & & & & Effectiveness & Predictability & Effectiveness & Predictability \\
\hline \multirow[t]{2}{*}{ Patient } & $\begin{array}{l}\text { Recession } \\
\text { Class }\end{array}$ & $\begin{array}{c}\text { Tooth } \\
\#\end{array}$ & $\begin{array}{c}\text { Initial } \\
\text { Recession } \\
\text { Defect } \\
\end{array}$ & $\begin{array}{c}4 \text { month } \\
\text { Recession } \\
\text { Defect } \\
\end{array}$ & $\begin{array}{c}\text { Recession } \\
\text { Defect } \\
\text { Coverage } \\
\end{array}$ & $\begin{array}{c}\text { Percent } \\
\text { Defect } \\
\text { Coverage } \\
\end{array}$ & $\begin{array}{c}\text { Frequency } \\
\geq 90 \% \text { Defect } \\
\text { Coverage }\end{array}$ & $\begin{array}{c}\text { Percent } \\
\text { Root } \\
\text { Coverage } \\
\end{array}$ & $\begin{array}{c}\text { Frequency } \\
\geq 90 \% \text { Root } \\
\text { Coverage }\end{array}$ \\
\hline & & & \multicolumn{3}{|c|}{ Millimeters } & Mean & Frequency & Mean & Frequency \\
\hline 1 & 1 & 9 & 3.0 & 0.0 & 3.0 & 100 & 1.0 & 100 & 1.0 \\
\hline 2 & 2 & 29 & 3.0 & 0.0 & 3.0 & 100 & 1.0 & 100 & 1.0 \\
\hline 3 & 1 & 23 & 3.0 & 0.0 & 3.0 & 100 & 1.0 & 100 & 1.0 \\
\hline 4 & 1 & 11 & 3.0 & 0.0 & 3.0 & 100 & 1.0 & 100 & 1.0 \\
\hline 5 & 1 & 6 & 3.0 & 0.0 & 3.0 & 100 & 1.0 & 100 & 1.0 \\
\hline 6 & 1 & 21 & 3.0 & 1.0 & 2.0 & 67 & 0.0 & 93 & 1.0 \\
\hline 7 & 2 & 6 & 4.0 & 0.0 & 4.0 & 100 & 1.0 & 100 & 1.0 \\
\hline 8 & 1 & 21 & 3.0 & 0.0 & 3.0 & 100 & 1.0 & 100 & 1.0 \\
\hline 9 & 1 & 6 & 3.0 & 0.0 & 3.0 & 100 & 1.0 & 100 & 1.0 \\
\hline 10 & 1 & 11 & 3.0 & 0.0 & 3.0 & 100 & 1.0 & 100 & 1.0 \\
\hline 11 & 1 & 11 & 3.0 & 0.0 & 3.0 & 100 & 1.0 & 100 & 1.0 \\
\hline \multirow[t]{4}{*}{12} & 1 & 11 & 3.0 & 0.0 & 3.0 & 100 & 1.0 & 100 & 1.0 \\
\hline & & & \multicolumn{3}{|c|}{ Mean (sd) } & Mean (sd) & Frequency & Mean (sd) & Frequency \\
\hline & & & 3.1 & 0.1 & $3.0 *$ & 97 & 11 of 12 & 99 & 12 of 12 \\
\hline & & & 0.3 & 0.3 & 0.4 & 10 & $92 \%$ & 2 & $100 \%$ \\
\hline
\end{tabular}

$*=\mathrm{p}<0.05$ between initial and 4 -month values 
Table 15

Recession, defect coverage, root coverage for control teeth treated with the tunnel procedure and a connective tissue graft.

\begin{tabular}{|c|c|c|c|c|c|c|c|c|c|}
\hline \multicolumn{3}{|c|}{ Patient Data } & \multicolumn{3}{|c|}{ Recession Data } & \multicolumn{2}{|c|}{ Defect Coverage } & \multicolumn{2}{|c|}{ Defect Elimination } \\
\hline & & & & & & Effectiveness & Predictability & Effectiveness & Predictability \\
\hline \multirow[t]{2}{*}{ Patient } & $\begin{array}{c}\text { Recession } \\
\text { Class }\end{array}$ & $\begin{array}{l}\text { Tooth } \\
\#\end{array}$ & $\begin{array}{c}\text { Initial } \\
\text { Recession } \\
\text { Defect } \\
\end{array}$ & $\begin{array}{c}4 \text { month } \\
\text { Recession } \\
\text { Defect } \\
\end{array}$ & $\begin{array}{c}\text { Recession } \\
\text { Defect } \\
\text { Coverage } \\
\end{array}$ & $\begin{array}{c}\text { Percent } \\
\text { Defect } \\
\text { Coverage } \\
\end{array}$ & $\begin{array}{c}\text { Frequency } \\
\geq 90 \% \text { Defect } \\
\text { Coverage }\end{array}$ & $\begin{array}{c}\text { Percent } \\
\text { Root } \\
\text { Coverage } \\
\end{array}$ & $\begin{array}{c}\text { Frequency } \\
\geq 90 \% \text { Root } \\
\text { Coverage }\end{array}$ \\
\hline & & & \multicolumn{3}{|c|}{ Millimeters } & Mean & Frequency & Mean & Frequency \\
\hline 1 & 1 & 6 & 3.0 & 0.0 & 3.0 & 100 & 1.0 & 100 & 1.0 \\
\hline 2 & 1 & 11 & 3.0 & 0.0 & 3.0 & 100 & 1.0 & 100 & 1.0 \\
\hline 3 & 1 & 21 & 3.0 & 0.0 & 3.0 & 100 & 1.0 & 100 & 1.0 \\
\hline 4 & 1 & 11 & 3.0 & 0.0 & 3.0 & 100 & 1.0 & 100 & 1.0 \\
\hline 5 & 2 & 21 & 3.0 & 0.0 & 3.0 & 100 & 1.0 & 100 & 1.0 \\
\hline 6 & 2 & 24 & 3.0 & 0.0 & 3.0 & 100 & 1.0 & 100 & 1.0 \\
\hline 7 & 2 & 25 & 3.0 & 0.0 & 3.0 & 100 & 1.0 & 100 & 1.0 \\
\hline 8 & 2 & 25 & 3.0 & 0.0 & 3.0 & 100 & 1.0 & 100 & 1.0 \\
\hline 9 & 2 & 24 & 3.5 & 2.0 & 1.5 & 43 & 0.0 & 85 & 0.0 \\
\hline 10 & 2 & 6 & 3.0 & 0.0 & 3.0 & 100 & 1.0 & 100 & 1.0 \\
\hline 11 & 2 & 28 & 3.0 & 0.0 & 3.0 & 100 & 1.0 & 100 & 1.0 \\
\hline \multirow[t]{4}{*}{12} & 1 & 29 & 3.0 & 0.0 & 3.0 & 100 & 1.0 & 100 & 1.0 \\
\hline & & & \multicolumn{3}{|c|}{ Mean (sd) } & Mean (sd) & Frequency & Mean (sd) & Frequency \\
\hline & & & 3.0 & 0.2 & $2.8^{*}$ & 95 & 11 of 12 & 99 & 11 of 12 \\
\hline & & & 0.1 & 0.6 & 0.4 & 16 & $92 \%$ & 4 & $92 \%$ \\
\hline
\end{tabular}

$*=\mathrm{p}<0.05$ between initial and 4 -month values 


\section{Table 16}

Visual Analog Scale of Pain and Esthetic Outcomes*

$\underline{\text { Mean } \pm \mathrm{sd}}$

\begin{tabular}{|lccccc|}
\hline Treatment & Surg Site & Palate & Surg Site & Palate & Esthetics \\
& $\mathbf{1 - 2}$ wks & $\mathbf{1 - 2}$ wks & $\mathbf{8}$ wks & $\mathbf{8}$ wks & 4 mo \\
\hline CT & $22 \pm 18$ & $35 \pm 32$ & $15 \pm 21$ & $25 \pm 30$ & $94 \pm 9$ \\
ADM & $20 \pm 20$ & & $10 \pm 10$ & & $97 \pm 5$ \\
\hline
\end{tabular}

* = scored on a $100 \mathrm{~mm}$ line 
Table 17

CT vs. ADM Studies: ADM Results

Mean $\pm \mathrm{sd}(\mathrm{mm})$

\begin{tabular}{|l|c|c|c|c|c|}
\hline Study & Year & $\begin{array}{c}\text { Initial } \\
\text { Recession }\end{array}$ & $\begin{array}{c}\text { Final } \\
\text { Recession }\end{array}$ & Change & $\begin{array}{c}\text { \% Defect } \\
\text { Coverage }\end{array}$ \\
\hline Harris & 2000 & 3.1 & 0.2 & 2.9 & 96 \\
\hline Aichelmann-Reidy et al. & 2001 & 2.5 & 0.8 & 1.7 & 66 \\
\hline Novaes et al. & 2001 & 3.2 & 1.1 & 2.1 & 67 \\
\hline Paolantonio et al. & 2002 & 4.8 & 0.7 & 4.0 & 83 \\
\hline Tal et al. & 2002 & 5.1 & 0.6 & 4.6 & 89 \\
\hline Harris & 2004 & 3.2 & 1.1 & 2.1 & 66 \\
\hline Hirsch et al. & 2005 & 4.2 & 0.2 & 4.0 & 96 \\
\hline Rahmani et al. & 2006 & 4.1 & 1.2 & 2.9 & 72 \\
\hline Joly et al. & 2007 & 4.2 & 2.1 & 2.1 & 50 \\
\hline Haghighati et al. & 2009 & 2.9 & 0.4 & 2.5 & 85 \\
\hline de Souza et al. & 2008 & 3.2 & 1.2 & 2.0 & 63 \\
\hline & & $3.7 \pm 0.8$ & $0.9 \pm 0.5$ & $2.8 \pm 1.0$ & $76 \pm 15$ \\
\hline
\end{tabular}


Table 18

CT vs. ADM Studies: CT Results

Mean $\pm \mathrm{sd}(\mathrm{mm})$

\begin{tabular}{|l|c|c|c|c|c|}
\hline Study & Year & $\begin{array}{c}\text { Initial } \\
\text { Recession }\end{array}$ & $\begin{array}{c}\text { Final } \\
\text { Recession }\end{array}$ & Change & $\begin{array}{c}\text { \% Defect } \\
\text { Coverage }\end{array}$ \\
\hline Harris & 2000 & 3.4 & 0.2 & 3.2 & 96 \\
\hline Aichelmann-Reidy et al. & 2001 & 3.0 & 0.8 & 2.2 & 74 \\
\hline Novaes et al. & 2001 & 3.0 & 1.1 & 1.8 & 65 \\
\hline Paolantonio et al. & 2002 & 4.8 & 0.5 & 4.3 & 89 \\
\hline Tal et al. & 2002 & 4.9 & 0.6 & 4.3 & 89 \\
\hline Harris & 2004 & 3.8 & 0.1 & 3.7 & 97 \\
\hline Hirsch et al. & 2005 & 4.9 & 0.1 & 4.8 & 98 \\
\hline Rahmani et al. & 2006 & 3.7 & 1.1 & 2.6 & 70 \\
\hline Joly et al. & 2007 & 4.4 & 0.9 & 3.5 & 80 \\
\hline Haghighati et al. & 2009 & 3.4 & 1.1 & 2.3 & 69 \\
\hline de Souza et al. & 2008 & 2.9 & 0.8 & 2.2 & 73 \\
\hline & & $3.8 \pm 0.8$ & $0.7 \pm 0.4$ & $3.2 \pm 1.0$ & $82 \pm 12$ \\
\hline
\end{tabular}




\section{Table 19}

Summary Table of Tunnel Maxillary vs. Mandibular Sites

Percent Defect Coverage Results

\begin{tabular}{|lccccc|}
\hline Study & Proc & Max n & Max \% & Mand n & Mand \% \\
\hline \hline Papageorgakopoulos & CPT & 6 & 95 & 6 & 62 \\
Shepherd & CPT & 3 & 100 & 6 & 54 \\
Shepherd & PRP & 2 & 100 & 7 & 85 \\
Shearer & Sing & 5 & 91 & 7 & 65 \\
Shearer & Cont & 4 & 100 & 8 & 75 \\
Mean $\pm \mathrm{sd}$ & & & $96 \pm 9$ & & $65 \pm 26$ \\
\hline
\end{tabular}




\section{CHAPTER IV}

\section{DISCUSSION}

The primary aim of this randomized, controlled, blinded clinical trial was to assess the clinical outcomes of a coronally positioned tunnel procedure plus either an acellular dermal matrix allograft (ADM) or a connective tissue graft (CT). Both the ADM and CT groups had a significant gain in mean recession defect coverage of $97 \%$ and $95 \%$, respectively $(\mathrm{p}<0.05)$. However, there were no statistically significant differences between groups $(p>0.05)$. Complete defect coverage was achieved $92 \%$ of the time ( 11 out of 12 sites) for both groups.

The CPT/ADM is a minimally invasive surgical technique that has no visible incisions and does not require a donor site. The use of a connective tissue graft with the tunnel technique has been previously reported, although the tissue was not coronally positioned in that study (Allen, 1994). Modifying the tunnel technique to include coronal positioning along with the use of a connective tissue graft has not been previously tested. Allen (1994) reported $95 \%$ defect coverage in sites with 1-3 mm of recession, which is similar to the $95 \%$ defect coverage obtained in this study. Since the results were virtually identical this indicates that coronal positioning of the tunnel does not improve the outcome in shallow recession sites. 
Previous CPT/ADM studies at this institution have indicated that maxillary sites respond better than mandibular sites, 96 vs 65\% respectively (Table 19). That was not the case in this study where $100 \%$ coverage was obtained in 11 of 12 sites in both the CT and the ADM groups. The 2 sites, 1 per group, that did not obtain complete defect coverage were mandibular sites. This study differed from the previous studies in that they contained a predominance of mandibular sites while this study contained a predominance of maxillary sites.

Most previous studies that have compared a CT graft to ADM have also used a coronally positioned flap technique (Table 17). The combined mean from these studies shows $82 \pm 12 \%$ defect coverage for CT studies vs. $76 \pm 15 \%$ for the ADM studies. This indicates that previous studies are in agreement and that there are minimal differences in defect coverage between the 2 techniques as reported in this study. This also indicates that a good result can be obtained with either the coronally positioned flap technique or the coronally positioned tunnel technique.

From 2 to 4 months both the ADM and CT groups showed a slight decrease in mean recession of $0.1 \mathrm{~mm}$ and $0.2 \mathrm{~mm}$, respectively (Table 13). This indicates a tendency for a minimal amount of coronal marginal tissue migration, also known as creeping attachment, after 2 months of healing. This differs from previous CPT studies at this institution that have shown a slight amount of marginal tissue retraction after 2 months of healing (Papageorgakopoulos 2008, Shepherd 2009, Shearer 2010). That difference may be explained by the site distribution in this study, which included mostly maxillary sites $(8 / 12)$. 
The width of keratinized tissue increased from time 0 to 4 months for the ADM and CT group by $0.3 \mathrm{~mm}$ and $0.4 \mathrm{~mm}$, respectively. Papageorgakopoulos et al. (2008) reported an increase of $0.8 \mathrm{~mm}$ using the CPT/ADM procedure while Shepherd et al. (2009) reported an increase of $0.4 \mathrm{~mm}$. In general, the use of the CPT/ADM seems to have minimal but usually positive effect on the keratinized tissue width.

Aichelmann-Reidy at al. (2001) compared the results between a CPF/CT and a CPF/ADM and obtained defect coverage of $74 \%$ and $66 \%$, respectively. That study also included an assessment of the esthetic outcomes. Independent clinicians and patients were asked to rate different esthetic aspects from 0 (unsatisfactory) to 3 points (excellent). Both the clinicians and patients gave the ADM higher scores for esthetic outcomes. In this study, the visual analog scale (VAS) means were $94 \mathrm{~mm}$ for CT group and $97 \mathrm{~mm}$ for ADM group. Therefore, the results obtained in this study agree with their findings although the difference between groups was minimal. They also recorded the subjective pain experience from both procedures and reported minimal pain for both. In this study, post-operative pain was separated by location as either at the graft site or at the palatal donor site. The VAS scores were significantly higher for the palatal site than the surgical site. The VAS scores for the surgical site, either CT or ADM, were similar although the ADM was slightly less.

Modarressi and Wang (2009), published a case series on the use of CPT/ADM in multiple adjacent maxillary teeth. Their study also included a subjective assessment of pain and esthetics. Patient discomfort was recorded 2 weeks postoperatively and was rated from 1 (mild) to 5 (severe). The mean discomfort score obtained from the 5 patients studied was 1.6. The overall quality assessment was recorded 6 months postoperatively. 
Patients had to agree or disagree to a short five questions questionnaire. Most of the patients agreed with the five quality outcome statements with only one disagreement with statements 1 and 2 . Even though this study assessed pain and esthetics with a different method (VAS), the results were similar.

In summary, a significant gain in defect coverage and attachment level was obtained following the coronally positioned tunnel technique combined with either an acellular dermal matrix allograft or a connective tissue autograft. There were no statistically significant differences in defect coverage between the two groups. Pain and esthetic scores were slightly better for the ADM group although the donor site pain scores were substantially higher for the CT group. The results obtained in this study suggest that either acellular dermal matrix or connective tissue combined with a coronally positioned tunnel technique are excellent option for treatment of recession defects. 


\section{CHAPTER V}

\section{CONCLUSIONS}

Within the limits of this study design it may be concluded that:

1) Both the connective tissue graft and the acellular dermal matrix allograft using the coronally positioned tunnel achieved a statistically significant amount of defect coverage, 97 vs. $95 \%$, respectively, although there were no statistically significant differences between groups.

2) The predictability of achieving complete defect coverage was equal for the ADM and the CT group, $92 \%$ vs. $92 \%$, respectively.

3) Patients reported a similar amount of post-operative pain at the ADM and CT surgical sites although the ADM was slightly less. Patients reported greater pain at the palatal donor sites than at the surgical sites.

4) Patients reported similar esthetic results for ADM and CT sites although the ADM sites scored slightly higher. 


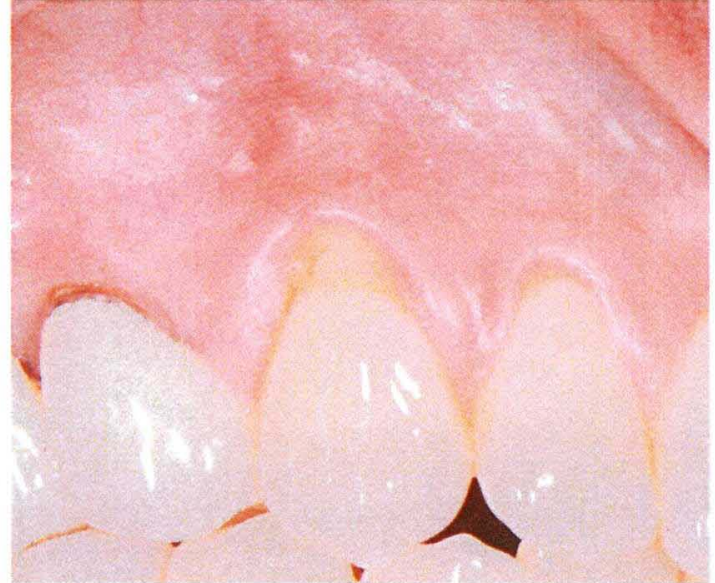

Figure 1a. Pre-op \#6

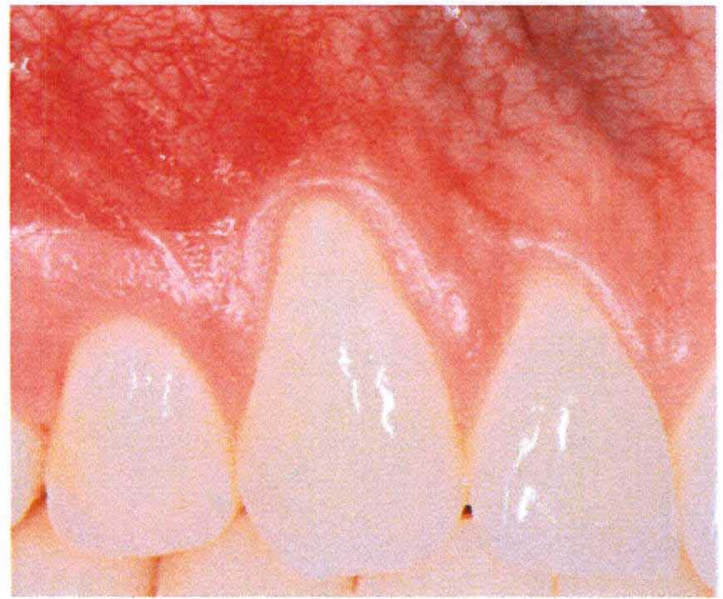

Figure 2a. Pre-op \#6

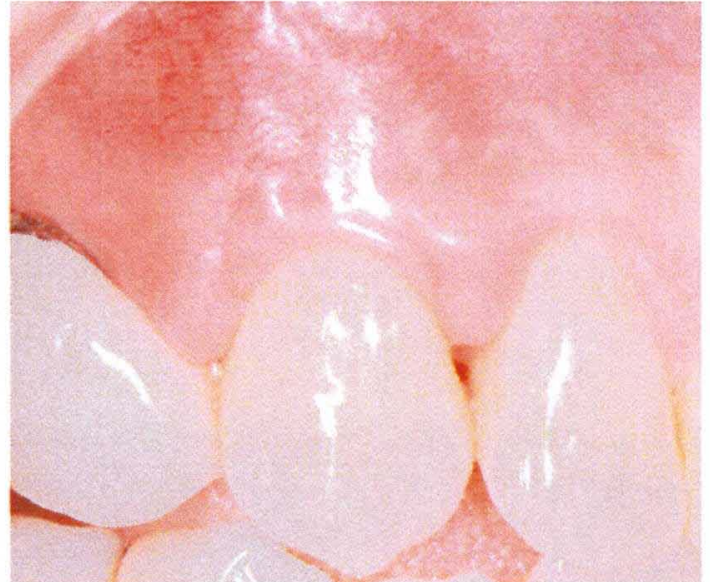

Figure 1b. 4-month post-op 6

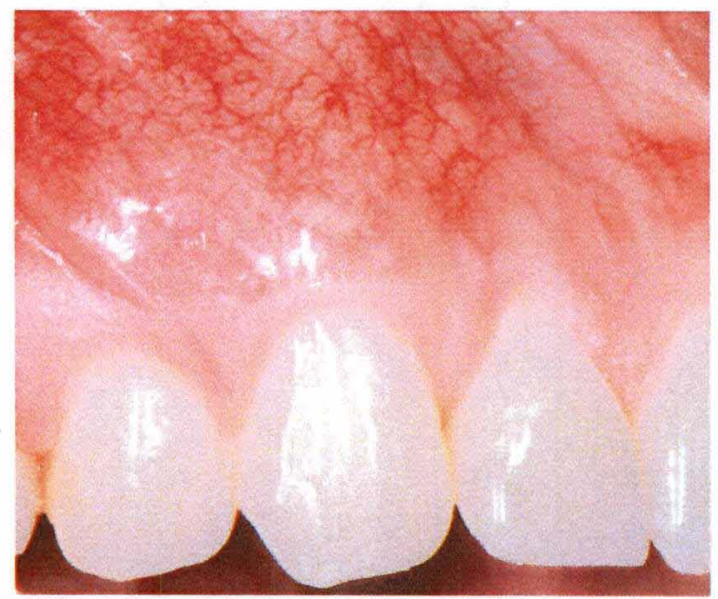

Figure 2b. 4-month post-op \#6

\section{Connective Tissue Graft Group}




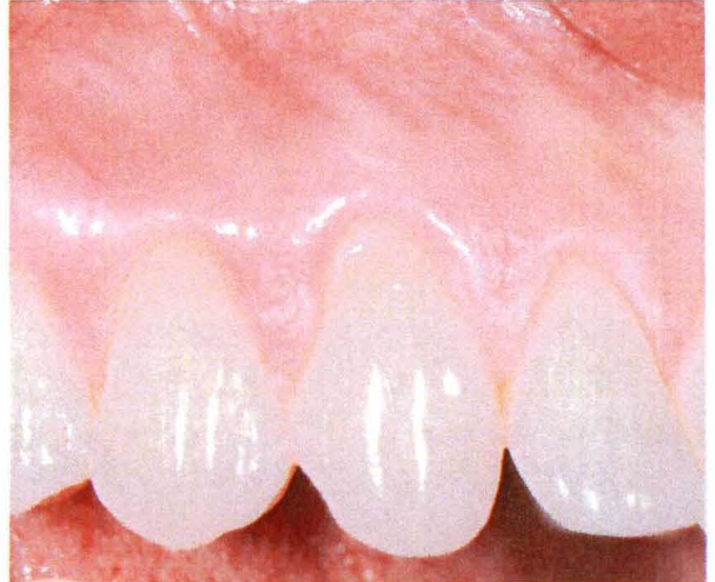

Figure 3a. Pre-op \#6

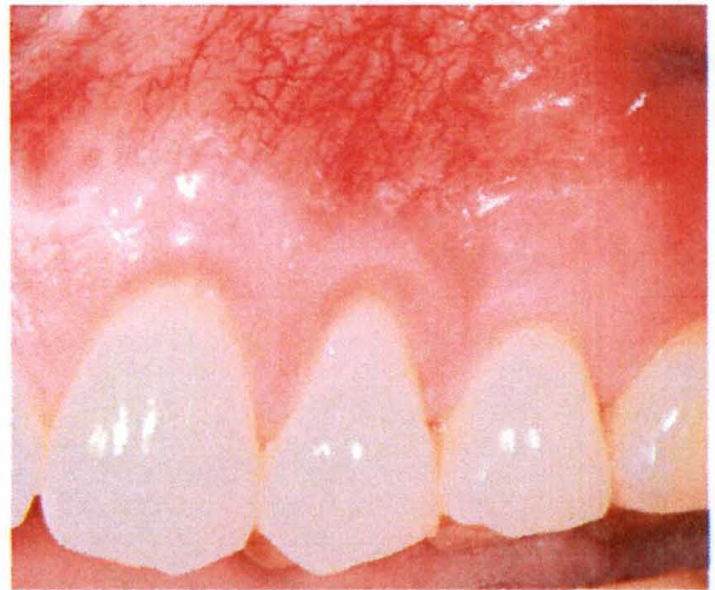

Figure 4a. Pre-op \#12

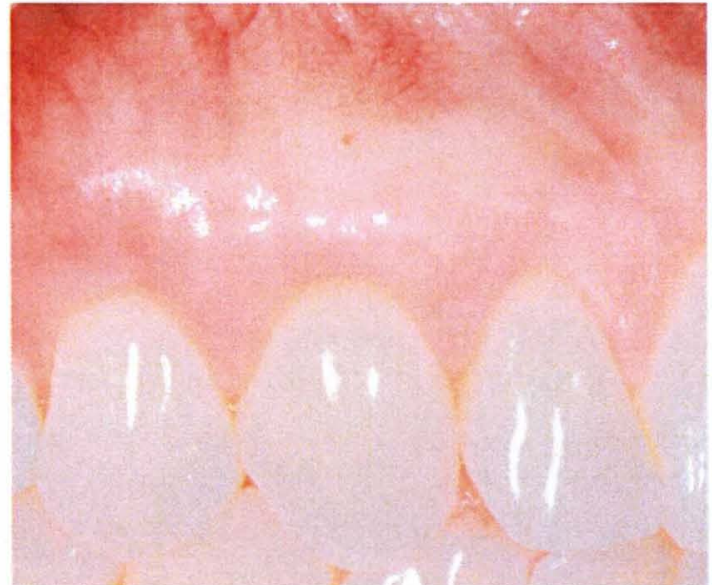

Figure 3b. 4-month post-op \#6

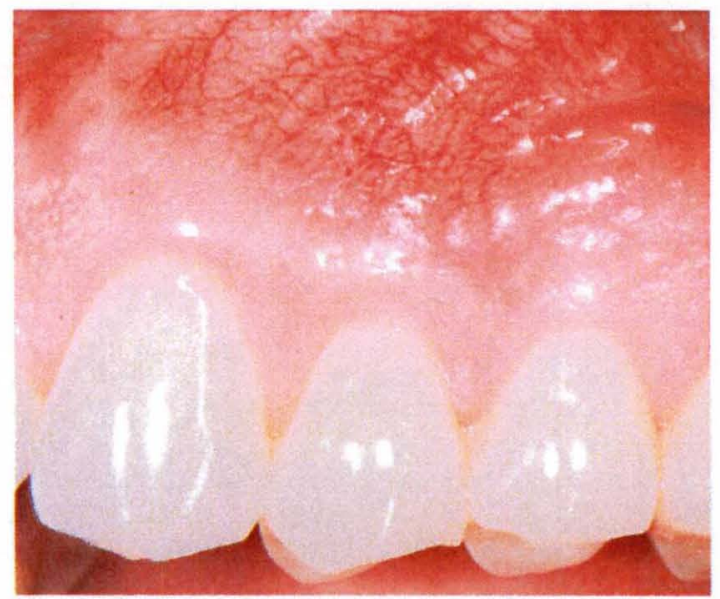

Figure 4b. 4-month post-op \#12

Acellular Dermal Matrix Group 


\section{REFERENCES}

Abolfazli N, Saleh-Saber F, Eskandari A, Lafzi A. A comparative study of the long term results of root coverage with connective tissue graft or enamel matrix protein: 24-month results. J West Soc Periodontol 2009;14(6):304-309.

Abundo R, Corrente G, Bermond des Ambrois A, Perelli M, Savio L. A connective tissue graft enveloppe technique for the treatment of single gingival recessions: a 1-year study. Int J Periodontics Restorative Dent 2009;29(6):593-597.

Aichelmann-Reidy ME, Yukna RA, Evans GH, Nasr HF, Mayer ET. Clinical evaluation of acellular allograft dermis for the treatment of human gingival recession. J Periodontol 2001;72:998-1005.

Al-Zahrani MS, Bissada NF, Ficara AJ, Cole B. Effect of connective tissue graft orientation on root coverage and gingival augmentation. Int $J$ Periodontics Restorative Dent 2004;24(1):65-69.

Albandar JM, Kingman A. Gingival recession, gingival bleeding and dental calculus in adults 30 years of age and older in the United States, 1988-1994. J Periodontol 1999;70:30-43.

Allen AL. Use of the supraperiosteal envelope in soft tissue grafting for root coverage. I. Rationale and technique. Int J Periodontics Restorative Dent 1994a;14(3):216-227.

Allen AL. Use of the supraperiosteal envelope in soft tissue grafting for root coverage. II. Clinical results. Int J Periodontics Restorative Dent 1994b;14(4):302-315.

Allen EP, Miller PD Jr. Coronal positioning of existing gingiva: short term results in the treatment of shallow marginal tissue recession. J Periodontol 1989;60:316-319.

Amarante ES, Leknes KN, Skavland J, Lie T. Coronally positioned flap procedures with or without a bioabsorbable membrane in the treatment of human gingival recession. $\mathrm{J}$ Periodontol 2000;71:989-998.

American Academy of Periodontology, Committee on Research Science and Therapy. Glossary of Periodontal Terms, Fourth Edition. 2001. 
Andia DC, Martins AG, Casati MZ, Sallum EA, Nociti FH. Root coverage outcome may be affected by heavy smoking: a 2-year follow-up study. J Periodontol 2008;79(4):64753 .

Andrade PF, Felipe ME, Novaes Jr AB, Souza SL, Taba Jr M, Palioto DB, Grisi MF. Comparison between two surgical techniques for root coverage with an acellular dermal matrix graft. J Clin Periodontol 2008;35:263-269.

Aranda JJ, Sanz M, Lazaro PJ. Surgical treatment of wide and isolated gingival recession. Guided tissue regeneration (GTR) versus supraperiosteal envelope technique: A randomized clinical study. (Abstract 115). J Dent Res 1996;75(Suppl):32.

Ariaudo AA. Problems in treating a denuded labial root surface of a lower incisor. J Periodontol 1966;37:274-278.

Armitage GC. Development of a classification system for periodontal diseases and conditions. Ann Periodontol 1999;4(1):1-6.

Aroca S, Keglevich T, Barbieri B, Gera I, Etienne D. Clinical evaluation of a modified coronally advanced flap alone or in combination with a platelet-rich fibrin membrane for the treatment of adjacent multiple gingival recessions: a 6-month study. J Periodontol 2009;80(2):244-52.

Baker D, Seymour G. The possible pathogenesis of gingival recession. J Clin Periodontol 1976;3:208-219.

Baldi C, Pini Prato G, Pagliaro U, Nieri M, Saletta D, Muzzi L, Cortellini P. Coronally advanced flap procedure for root coverage. Is flap thickness a relevant predictor to achieve root coverage? A 19-case series. J Periodontol 1999;70:1077-1084.

Banihashemrad A, Aghassizadeh E, Radvar M. Treatment of gingival recessions by guided tissue regeneration and coronally advanced flap. N Y State Dent J 2009;75(1):5458 .

Barros RR, Novaes AB, Grisi MF, Souza SL, Taba M, Palioto DB. A 6-month comparative clinical study of a conventional and a new surgical approach for root coverage with acellular dermal matrix. J Periodontol 2004;75(10):1350-1356.

Bernimoulin JP, Luscher B, Mühlemann HR. Coronally repositioned periodontal flap. Clinical evaluation after one year. J Clin Periodontol 1975;2:1-13. 
Bittencourt S, Ribeiro Edel P, Sallum EA, Sallum AW, Nociti FH, Casati MZ. Semilunar coronally positioned flap or subepithelial connective tissue graft for the treatment of gingival recession: a 30-month follow-up study. J Periodontol 2009;80(7):1076-82.

Bittencourt S, Ribeiro EDP, Sallum EA, Sallum AW, Nociti Jr FH, Casati MZ. Comparative 6-month clinical study of a semilunar coronally positioned flap and subepithelial connective tissue graft for the treatment of gingival recession. J Periodontol 2006;77(2):174-181.

Bjorn H. Free transplantation of gingiva propria. Swedish Dent J 1963;22:684-689.

Blanes RJ, Allen EP. The bilateral pedicle flap-tunnel technique: a new approach to cover connective tissue grafts. Int J Periodontics Restorative Dent 1999;19(5):471-479.

Borghetti A, Glise J, Monnet-Corti V, Dejou J. Comparative clinical study of a bioabsorable membrane and subepithelial connective tissue graft in the treatment of human gingival recession. J Periodontol 1999;70:123-130.

Borghetti A, Louise F. Controlled clinical evaluation of the subpedicle connective tissue graft for the coverage of gingival recession. J Periodontol 1994;65:1107-1112.

Bouchard P, Etienne D, Ouhayoun JP, Nilveus R. Subepithelial connective tissue grafts in the treatment of gingival recessions. A comparative study of 2 procedures. $J$ Periodontol 1994;65:929-936.

Bouchard P, Nilveus R, Etienne D. Clinical evaluation of tetracycline $\mathrm{HCl}$ conditioning in the treatment of gingival recession. A comparative study. J Periodontol 1997;68:262269.

Bruno JF. Connective tissue graft technique assuring wide root coverage. Int $\mathrm{J}$ Periodontics Restorative Dent 1994;14(2):126-137.

Bruno JF, Bowers GM. Histology of human biopsy section following the placement of a subepithelial connective tissue graft. Int J Periodontics Restorative Dent 2000;20(3):225231.

Burkhardt R, Lang NP. Coverage of localized gingival recessions: Comparison of microand macrosurgical techniques. J Clin Periodontol 2005;32(3):287-293.

Butler BL. The subepithelial connective tissue graft with a vestibular releasing incision. $\mathbf{J}$ Periodontol 2003;74(6):893-898. 
Byun HY, Oh TJ, Abuhussein HM, Yamashita J, Soehren SE, Wang HL. Significance of the epithelial collar on the subepithelial connective tissue graft. J Periodontol 2009;80(6):924-932.

Caffesse RG, De LaRosa M, Garza M, Munne-Travers A, Mondragon JG, Weltman R. Citric acid demineralization and subepithelial connective tissue grafts. J Periodontol 2000;71:568-572.

Cardaropoli D, Cardaropoli G. Healing of gingival recessions using a collagen membrane with a hemineralized xenograft: a randomized controlled clinical trial. Int J Periodontics Restorative Dent 2009;29(1):59-67.

Carnio J, Camargo PM, Kenney EB. Root resorption associated with a subepithelial connective tissue graft for root coverage: clinical and histologic report of a case. Int $\mathrm{J}$ Periodontics Restorative Dent 2003;23(4):391-398.

Carvalho PF, da Silva RC, Curry PR, Joly JC. Modified coronally advanced flap associated with a subepithelial connective tissue graft for the treatment of adjacent multiple gingival recessions. J Periodontol 2006;77(11):1901-1906.

Castellanos A, de la Rosa R M, de la Garza M, Caffesse RG. Enamel matrix derivative and coronal flaps to cover marginal tissue recessions. J Periodontol 2006; 77(1):7-14.

Cetiner D, Bodur A, Uraz A. Expanded mesh connective tissue graft for the treatment of multiple gingival recessions. J Periodontol 2004;75(8):1167-1172.

Cetiner D, Parlar A, Balos K, Alpar R. Comparative clinical study of connective tissue graft and two types of bioabsorbable barriers in the treatment of localized gingival recessions. J Periodontol 2003;74(8):1196-1205.

Chambrone LA, Chambrone L. Subepithelial connective tissue grafts in the treatment of multiple recession-type defects. J Periodontol 2006;77(5):909-916.

Cheung WS, Griffin TJ. A comparative study of root coverage with connective tissue and platelet concentrate grafts: 8-month results. J Periodontol 2004;75(12): 1678-1687.

Cordioli G, Mortarino C, Chierico A, Grusovin MG, Majzoub Z. Comparison of 2 techniques of subepithelial connective tissue graft in the treatment of gingival recessions. J Periodontol 2001;72:1470-1476.

Cortellini P, Tonetti M, Baldi C, Francetti L, Rasperini G, Rotundo R, Nieri M, Franceschi D, Labriola A, Prato GP. Does placement of a connective tissue graft improve the outcomes of coronally advanced flap for coverage of single gingival recessions in 
upper anterior teeth? A multi-centre, randomized, double-blind, clinical trial. J Clin Periodontol 2009;36(1):68-79.

Cortes A, Martins AG, Nociti FH, Sallum AW, Casati MZ, Sallum EA. Coronally positioned flap with or without acellular dermal matrix graft in the treatment of class I gingival recessions: A randomized controlled clinical study. J Periodontol 2004;75(8):1137-1144.

Cummings LC, Kaldahl WB, Allen EP. Histologic evaluation of autogenous connective tissue and acellular dermal matrix grafts in humans. J Periodontol 2005;76(2):178-186.

da Silva RC, Joly JC, de Lima AF, Tatakis DN. Root coverage using the coronally positioned flap with or without a subepithelial connective tissue graft. J Periodontol 2004;75:413-419.

de Queiroz Cortes A, Sallum AW, Casati MZ, Nociti FH, Sallum EA. A two-year prospective study of coronally positioned flap with or without acellular dermal matrix graft. J Clin Periodontol 2006;33(9):683-689.

De Sanctis M, Zucchelli G. Coronally advanced flap: a modified surgical approach for isolated recession-type defects: three-year results. J Clin Periodontol 2007;34(3):262-268.

de Souza SL, Macedo GO, Tunes RS, Silveira e Souza AM, Novaes Jr AB, Grisi MF, Taba M Jr, Palioto DB, Correa VM. Subepithelial connective tissue graft for root coverage in smokers and non-smokers: A clinical and histologic controlled study in humans. J Periodontol 2008;79(6):1014-1021.

de Souza SL, Novaes AB Jr, Grisi DC, Taba M Jr, de Andrade PF. Comparative clinical study of a subepithelial connective tissue graft and acellular dermal matrix graft for the treatment of gingival recessions: six- to 12-month changes. J Int Acad Periodontol 2008:10(3):87-94.

Del Pizzo M, Zucchelli G, Modica F, Villa R, Debernardi C. Coronally advanced flap with or without enamel matrix derivative for root coverage: a 2-year study. J Clin Periodontol 2005;32(11):1181-1187.

Dembowska E, Drozdzik A. Subepithelial connective tissue graft in the treatment of multiple gingival recession. Oral Surg Oral Med Oral Pathol Oral Radiol Endod 2007;104(3):1-7.

Dodge JR, Henderson R, Greenwell H. Root coverage without a palatal donor site using an acellular dermal graft. Periodontal Insights 1998;5:5-8. 
Edel A. Clinical Evaluation of Free Connective Tissue Grafts Used to Increase the width of Keratinized Gingiva J Clin Periodontol 1974;1:185-196.

Erley KJ, Swiec GD, Herold R, Bisch FC, Peacock ME. Gingival recession treatment with connective tissue grafts in smokers and non-smokers. J Periodontol 2006;77(7):1148-1155.

Felipe ME, Andrade PF, Grisi MF, Souza SL, Taba M, Palioto DB, Novaes AB. Comparison of two surgical procedures for use of the acellular dermal matrix graft in the treatment of gingival recessions: A randomized controlled clinical study. J Periodontol 2007;78(7):1209-1217.

Francetti L, Del Fabbro M, Testori T, Weinstein RL. Periodontal microsurgery: Report of 16 cases consecutively treated by the free rotated papilla autograft technique combined with the coronally advanced flap. Int J Periodontics Restorative Dent 2004;24(3):272279.

Fu JH, Hasso DG, Yeh CY, Leong DJM, Chan HL, Wang HL. The accuracy of identifying the greater palatine neurovascular bundle: A cadaver study. J Periodontol 2011;82(7):1000-1006.

Gartrell JR, Matthews D. Gingival recession. The condition, process, and treatment. Dent Clin North Am 1976;20(1):199-213.

Georges P, Nisand D, Etienne D, Mora F. Efficacy of the supraperiosteal envelope technique: a preliminary comparative clinical study. Int J Periodontics Restorative Dent 2009;29(2):201-11.

Goldman H, Schluger S, Fox L, Cohen D. Periodontal therapy. C.V.Mosby, St. Louis 1964; 3rd ed 560.

Goldstein M, Boyan BD, Cochran DL, Schwartz Z. Human histology of new attachment after root coverage using subepithelial connective tissue graft. J Clin Periodontol 2001;28(7):657-662.

Goldstein M, Nasatzky E, Goultschin J, Boyan BD, Schwartz Z. Coverage of previously carious roots is as predictable a procedure as coverage of intact roots. $\mathrm{J}$ Periodontol 2002;73:1419-1426.

Gorman WJ. Prevalence and etiology of gingival recession. J Periodontol 1967;38:316322. 
Gottlow J, Nyman S, Karring T, Lindhe J. Treatment of localized gingival recessions with coronally displaced flaps and citric acid. An experimental study in the dog. J Clin Periodontol 1986;13:57-63.

Green L, Levin M. Treatment of an unusual case of incipient gingival recession exhibiting a familial tendency: A case report. J Periodontol 1973;44(8):519-524.

Greenwell H, Fiorellini J, Giannobile W, Offenbacher S, Salkin L, Townsend C, Sheridan P, Genco R; Research, Science and Therapy Committee Oral reconstructive and corrective considerations in periodontal therapy. J Periodontol 2005;76(9):1588-1600.

Gunay H, Dogan S, Geurtsen W. Harvesting technique using a mucotome and modified surgical procedure for root coverage with enamel matrix derivatives with and without a connective tissue graft. Int J Periodontics Restorative Dent 2008;28(5):497-507.

Hagewald S, Spahr A, Rompola E, Haller B, Heijl L, Bernimoulin JP. Comparative study of Emdogain and coronally advanced flap technique in the treatment of human gingival recessions. A prospective controlled clinical study. J Clin Periodontol 2002;29:35-41.

Haghighati F, Mousavi M, Moslemi N, Kebria MM, Golestan B. A comparative study of two root-coverage techniques with regard to interdental papilla dimension as a prognostic factor. Int J Periodontics Restorative Dent 2009;29(2):179-89.

Han JS, John V, Blanchard SB, Kowolik MJ, Eckert GJ. Changes in gingival dimensions following connective tissue grafts for root coverage: comparison of two procedures. $\mathrm{J}$ Periodontol 2008;79(8):1346-1354.

Harris RJ. The connective tissue and partial thickness double pedicle graft: a predictable method of obtaining root coverage. J Periodontol 1992;63:477-486.

Harris RJ. The connective tissue with partial thickness double pedicle graft: the results of 100 consecutively-treated defects. J Periodontol 1994;65:448-461.

Harris RJ. A comparative study of root coverage obtained with guided tissue regeneration utilizing a bioabsorbable membrane versus the connective tissue with partial-thickness double pedicle graft. J Periodontol 1997;68:779-790.

Harris RJ. A comparison of 2 root coverage techniques: guided tissue regeneration with a bioabsorbable matrix style membrane versus a connective tissue graft combined with a coronally positioned pedicle graft without vertical incisions. Results of a series of consecutive cases. J Periodontol 1998a;69:1426-1434. 
Harris RJ. Root coverage with a connective tissue with partial thickness double pedicle graft and an acellular dermal matrix graft: A clinical and histological evaluation of a case report. J Periodontol 1998b;69:1305-1311.

Harris RJ. Human histologic evaluation of root coverage obtained with a connective tissue with partial thickness double pedicle graft. A case report. J Periodontol $1999 \mathrm{a} ; 70: 813-821$.

Harris RJ. Successful root coverage: A human histologic evaluation of a case. Int J Periodontics Restorative Dent 1999b;19(5):439-448.

Harris RJ. A comparative study of root coverage obtained with an acellular dermal matrix versus a connective tissue graft: Results of 107 recession defects in 50 consecutively treated patients. Int J Periodontics Restorative Dent 2000;20(1):51-59.

Harris RJ. Gingival augmentation with an acellular dermal matrix: human histologic evaluation of a case - placement of the graft on bone. Int J Periodontics Restorative Dent $2001 ; 21(1): 69-75$.

Harris RJ. Connective tissue grafts combined with either double pedicle grafts or coronally positioned pedicle grafts: results of 266 consecutively treated defects in 200 patients. Int J Periodontics Restorative Dent 2002a;22(5):463-471.

Harris RJ. Root coverage with connective tissue grafts: an evaluation of short- and longterm results. J Periodontol 2002b;73:1054-1059.

Harris RJ. Acellular dermal matrix used for root coverage: 18-month follow-up observation. Int J Periodontics Restorative Dent 2002c;22(2):156-163.

Harris RJ. Root coverage in molar recession: report of 50 consecutive cases treated with subepithelial connective tissue grafts. J Periodontol 2003;74:703-708.

Harris RJ. A short-term and long-term comparison of root coverage with an acellular dermal matrix and a subepithelial graft. J Periodontol 2004;75(5):734-743.

Harris RJ, Harris AW. The coronally positioned pedicle graft with inlaid margins: a predictable method of obtaining root coverage of shallow defects. Int J Periodontics Restorative Dent 1994;14(3):228-241.

Harris RJ, Harris LE, Harris CR, Harris AJ. Evaluation of root coverage with two connective tissue grafts obtained from the same location. Int J Periodontics Restorative Dent 2007;27(4):333-339. 
Harris RJ, Miller LH, Harris CR, Miller RJ. A comparison of three techniques to obtain root coverage on mandibular incisors. J Periodontol 2005;76(10):1758-1767.

Henderson RD, Greenwell H, Drisko C, Regennitter FJ, Lamb JW, Mehlbauer MJ, Goldsmith LJ, Rebitski G. Predictable multiple site root coverage using an acellular dermal matrix allograft. J Periodontol 2001;72;571-582.

Hirsch A, Goldstein M, Goultschin J, Boyan BD, Schwartz Z. A 2-year follow-up of root coverage usig subpedicle acellular dermal matrix allografts and subepithelial connective tissue autografts. J Periodontol 2005;76(8):1323-1328.

Hirschfeld I. A study of skulls in the American Museum of Natural History in relation to periodontal diseases. J Dent Res 1923;5:241-265.

Hirschfeld I. Toothbrush trauma recession. A clinical study. J Dent Res 1931;11(1):6163.

Huang LH, Neiva RE, Wang HL. Factors affecting the outcomes of coronally advanced flap root coverage procedure. J Periodontol 2005a;76(10):1729-1734.

Huang LH, Neiva REF, Soehren SE, Giannobile WV, Wang HL. The effect of plateletrich plasma on the coronally advanced flap root coverage procedure: A pilot human trial. J Periodontol 2005b;76(10):1768-1777.

Hugoson A, Norderyd O. Has the prevalence of periodontitis changed during the last 30 years? J Clin Periodontol 2008;35(Suppl.8):338-345.

Jahnke PV, Sandifer JB, Gher ME, Gray JL, Richardson AC. Thick free gingival and connective tissue autografts for root coverage. J Periodontol 1993;64:315-322.

Jankovic SM, Zoran AM, Lekovic MV, Bozidar DS, Kenney BE. The use of platelet-rich plasma in combinatin with connective tissue grafts following tratment of gingival recessions. Periodontal Practice Today 2007;4:63-71.

Jepsen K, Heinz B, Halben JH, Jepsen S. Treatment of gingival recession with titanium reinforced barrier membranes versus connective tissue grafts. J Periodontol 1998;69:383391.

Jhaveri HM, Chavan MS, Tomar GB, Deshmukh VL, Wani MR, Miller PD. Acellular dermal matrix seeded with autologous gingival fibroblasts for the treatment of gingival recession: a proof-of-concept study. J Periodontol 2010;81(4):616-625. 
Joly JC, Carvalho AM, da Silva RC, Ciotti DL, Cury PR. Root coverage in isolated gingival recessions using autograft versus allograft: A pilot study. J Periodontol 2007;78(6):1017-1022.

Karring T, Ostergaard E, Loe $\mathrm{H}$. Conservation of tissue specificity after heterotopic transplantation of gingiva and alveolar mucosa. J Periodont Res 1971;6:282-293.

Kassab MM, Cohen RE, Andreana S, Dentino AR. The effect of EDTA in attachment gain and root coverage. Compend Contin Educ Dent 2006;27(6):353-360.

Kitchin PC. The Prevalence of Tooth Root Exposure, and the Relation of the Extent of Such Exposure to the Degree of Abrasion in Different Age Classes. J Dent Res $1941 ; 20: 565-581$

Langer B, Calagna L. The subepithelial connective tissue graft. J Prosthet Dent 1980;44:363-367.

Langer B, Calagna LJ. The subepithelial connective tissue graft. A new approach to the enhancement of anterior cosmetics. Int J Periodontics Restorative Dent 1982;2(2):22-33.

Langer B, Langer L. Subepithelial connective tissue graft technique for root coverage. J Periodontol 1985;56:715-720.

Laster L, Laudenbach K, Stoller N. An evaluation of clinical tooth mobility measurements. J Periodontol 1975;46(10):603-607.

Lee YM, Kim JY, Seol YJ, Lee YK, Ku Y, Rhyu IC, Han SB, Choi SM, Chung CP. A 3year longitudinal evaluation of subpedicle free connective tissue graft for gingival recession coverage. J Periodontol 2002;73:1412-1418.

Leknes KN, Amarante ES, Price DE, Boe OE, Skavland RJ, Lie T. Coronally positioned flap procedures with or without a biodegradable membrane in the treatment of human gingival recession. A 6-year follow-up study. J Clin Periodontol 2005;32(5):518-529.

Levine RA. Covering denuded maxillary root surfaces with the subepithelial connective tissue graft. Compend Contin Educ Dent 1991;12:568,570,572 passim.

Lins LH, de Lima AF, Sallum AW. Root coverage: Comparison of coronally positioned flap with and without titanium-reinforced barrier membrane. J Periodontol 2003;74:168174.

Lobene RR, Weatherford T, Ross NM, Lamm RA, Menaker L. A modified gingival index for use in clinical trials. Clin Prev Dent 1986;8(1):3-6. 
Loe H, Anerud A, Boysen H. The natural history of periodontal disease in man: prevalence, severity, and extent of gingival recession. J Periodontol 1992;63:489-495.

Löst C. Depth of alveolar bone dehiscences in relation to gingival recessions. J Clin Periodontol 1984;11:583-589.

Majzoub Z, Landi L, Grusovin MG, Cordioli G. Histology of connective tissue graft. A case report. J Periodontol 2001;72:1607-1615.

Martins AG, Andia DC, Sallum AW, Sallum EA, Casati MZ, Nociti FH Jr. Smoking may affect root coverage outcome: A prospective clinical study in humans. J Periodontol 2004;75:586-591.

Matter J. Creeping attachment of free gingival grafts. A five-year follow-up study. J Periodontol 1980;51:681-685.

McGuire MK, Nunn M. Evaluation of human recession defects treated with coronally advanced flaps and either enamel matrix derivative or connective tissue. Part 1: Comparison of clinical parameters. J Periodontol 2003;74:1110-1125.

Mehlbauer MJ, Greenwell H. Complete root coverage at multiple sites using an acellular dermal matrix allograft. Compend Contin Educ Dent 2005;26(10):727-733.

Milano F. A combined flap for root coverage. Int $\mathrm{J}$ Periodontics Restorative Dent 1998;18(6):544-551.

Miller PD Jr. A classification of marginal tissue recession. Int J Periodontics Restorative Dent 1985;5(2):8-13.

Modarressi M, Wang HL. Tunneling procedure for root coverage using acellular dermal matrix: a case series. Int J Periodontics Restorative Dent 2009;29(4):395-403.

Modica F, DelPizzo M, Roccuzzo M, Romagnoli R. Coronally advanced flap for the treatment of buccal gingival recessions with and without enamel matrix derivative. A split-mouth study. J Periodontol 2000;71:1693-1698.

Monnet-Corti V, Santini A, Glise JM, Fouque-Deruelle C, Dillier FL, Liebart MF, Borghetti A. Connective tissue graft for gingival recession treatment: assessment of the maximum graft dimensiions at the palatal vault as a donor site. J Periodontol 2006;77(5):899-902. 
Moses O, Artzi Z, Sculean A, Tal H, Kozlovsky A, Romanos GE, Nemcovsky CE. Comparative study of two root coverage procedures: A 24-month follow-up multicenter study. J Periodontol 2006;77(2):195-202.

Müller HP, Eger T, Schorb A. Gingival dimensions after root coverage with free connective tissue grafts. J Clin Periodontol 1998;25:424-430.

Muller HP, Stahl M, Eger T. Root coverage employing an envelope technique or guided tissue regeneration with a bioabsorbable membrane. J Periodontol 1999;70:743-751.

Müller HP, Stahl M, Eger T. Failure of root coverage of shallow gingival recessions employing GTR and a bioresorbable membrane. Int J Periodontics Restorative Dent 2001;21(2):171-181.

Nabers JM. Free gingival grafts. Periodontics 1966;4(5)243-245.

Nelson SW. The subpedicle connective tissue graft. A bilaminar reconstructive procedure for the coverage of denuded root surfaces. J Periodontol 1987;58:95-102.

Nemcovsky CE, Artzi Z, Tal H, Kozlovsky A, Moses O. A multicenter comparative study of two root coverage procedures: coronally advanced flap with addition of enamel matrix proteins and subpedicle connective tissue graft. J Periodontol 2004;75:600-607.

Novaes AB, Grisi DC, Molina GO, Souza SL, Taba M, Grisi MF. Comparative 6-month clinical study of a subepithelial connective tissue graft and acellular dermal matrix graft for the treatment of gingival recession. J Periodontol 2001;72:1477-1484.

Ozcelik O, Haytac MC, Seydaoglu G. Treatment of multiple gingival recessions using a coronally advanced flap procedure combined with button application. J Clin Periodontol 2011;38:572-580.

Paolantonio M. Treatment of gingival recessions by combined periodontal regenerative technique, guided tissue regeneration and subpedicle connective tissue graft. A comparative clinical study. J Periodontol 2002;73:53-62.

Paolantonio M, di Murro C, Cattabriga A, Cattabriga M. Subpedicle connective tissue graft versus free gingival graft in the coverage of exposed root surfaces. A 5-year clinical study. J Clin Periodontol 1997;24:51-56.

Paolantonio M, Dolci M, Esposito P, D'Archivio D, Lisanti L, Di Luccio A, Perinetti G. Subpedicle acellular dermal matrix graft and autogenous connective tissue graft in the treatment of gingival recessions: a comparative 1-year clinical study. J Periodontol 2002;73:1299-1307. 
Papageorgakopoulos G, Greenwell H, Hill M, Vidal R, Scheetz JP. Root coverage using an acellular dermal matrix and comparing a coronally positioned tunnel to a coronally positioned flap approach. J Periodontol 2008;79(6):1022-1030.

Pattison GL. Self-inflicted gingival injuries: Literature review and case report. J Periodontol 1983;54(5):299-304.

Pilloni A, Paolantonio M, Camargo PM. Root coverage with a coronally positioned flap used in combination with enamel matrix derivative: 18-month clinical evaluation. J Periodontol 2006;77(12):2031-2039.

Pini Prato G, Baldi C, Pagliaro U, Nieri M, Saletta D, Rotundo R, Cortellini P. Coronally advanced flap procedure for root coverage. Treatment of root surface: root planing vs. polishing. J Periodontol 1999;70:1064-1076.

Pini Prato G, Franceschi D, Cairo F, Nieri M, Rotundo R. Classification of dental surface defects in areas of gingival recession. J Periodontol 2010a;81(6):885-890.

Pini Prato G, Pagliaro U, Baldi C, Nieri M, Saletta D, Cairo F, Cortellini P. Coronally advanced flap procedure for root coverage. Flap with tension versus flap without tension: a randomized controlled clinical study. J Periodontol 2000;71:188-201.

Pini Prato GP, Baldi C, Nieri M, Franseschi D, Corttllini P, Clauser C, Rotundo R. Muzzi L. Coronally advanced flap: The post-surgical position of the gingival margin is an important factor for achieving complete root coverage. J Periodontol 2005;76(5):713722.

Pini Prato GP, Cairo F, Nieri M, Franceschi D, Rotundo R, Cortellini P. Coronally advanced flap versus connective tissue graft in the treatment of multiple gingival recessions: a split-mouth study with a 5-year follow-up. J Clin Periodontol 2010b;37:644650.

Pini Prato GP, Rotundo R, Magnani C, Ficarra G. Viral etiology of gingival recession: A case report. J Periodontol 2002;73:110-114.

Raetzke PB. Covering localized areas of root exposure employing the "envelope" technique. J Periodontol 1985;56:397-402.

Rahmani ME, Lades MA. Comparative clinical evaluation of acellular dermal matrix allograft and connective tissue graft for the treatment of gingival recession. J Clin Periodontol 2006;7(2):63-70. 
Rasperini G, Francetti L, Consonni D. Subepithelial connective tissue graft for treatment of gingival recessions with and without enamel matrix derivative: a multicenter, randomized controlled clinical trial. Int J Periodontics Restorative Dent 2011;31(2):133139.

Reiser GM, Bruno JF, Mahan PE, Larkin LH. The subepithelial connective tissue graft palatal donor site; anatomic considerations for surgeons. Int J Periodontics Restorative Dent 1996;16(2):130-137.

Ricci G, Silvestri M, Tinti C, Rasperini G. A clinical/statistical comparison between the subpedicle connective tissue graft method and the guided tissue regeneration technique in root coverage. Int J Periodontics Restorative Dent 1996;16(6):538-545.

Romagna-Genon C. Comparative clinical study of guided tissue regeneration with a bioabsorbable bilayer collagen membrane and subepithelial connective tissue graft. J Periodontol 2001;72:1258-1264.

Roman A, Campian R, Domsa I, Soanca A, Gocan H. Subepithelial connective tissue graft for root coverage: clinical case reports and histologic evaluation. Romanian Journal of Morph and Emb 2010;51(4):793-797.

Romanos G, Bernimoulin JP, Marggraf E. The double lateral bridging flap for coverage of denuded root surface: longitudinal study and clinical evaluation after 5 to 8 years. $\mathbf{J}$ Periodontol 1993;64:683-688.

Rosetti EP, Marcantonio RA, Rossa C Jr, Chaves ES, Goissis G, Marcantonio E Jr. Treatment of gingival recession: comparative study between subepithelial connective tissue graft and guided tissue regeneration. J Periodontol 2000;71:1441-1447.

Saletta D, Pini Prato G, Pagliaro U, Baldi C, Mauri M, Nieri M. Coronally advanced flap procedure: is the interdental papilla a prognostic factor of root coverage? J Periodontol 2001;72:760-766.

Santana RB, Mattos CML, Dibart S. A clinical comparison of two flap designs for coronal advancement of the gingival margin: semilunar versus coronally advanced flap. $\mathrm{J}$ Clin Periodontol 2010;37:651-658.

Santos A, Goumenos G, Pascual A. Management of gingival recession by the use of an acellar dermal graft material: A 12-case series. J Periodontol 2005;76(11):1982-1990.

Serino G, Wennstrom JL, Lindhe J, Eneroth L. The prevalence and distribution of gingival recession in subjects with high standard of oral hygiene. J Clin Periodontol 1994;21:57-63. 
Shepherd N, Greenwell H, Hill M, Vidal R, Scheetz JP. Root coverage using acellular dermal matrix and comparing a coronally positioned tunnel with and without platelet-rich plasma: a pilot study in humans. J Periodontol 2009;80(3):397-404.

Silness J, Löe H. Periodontal disease in pregnancy. II. Correlation between oral hygiene and periodontal conditions. Acta Odontol Scand 1964;22(1):121-135.

Silva CO, Sallum AW, de Lima AF, Tatakis DN. Coronally positioned flap for root coverage: poorer outcomes in smokers. J Periodontol 2006;77(1):81-7.

Smith RG. Gingival recession. Reappraisal of an enigmatic condition and a new index for monitoring. J Clin Periodontol 1997;24:201-205.

Spahr A, Haegewald S, Tsoulfidou F, Rompola E, Heijl L, Bernimoulin JP, Ring C, Sander S, Haller B. Coverage of Miller class I and II recession defects using enamel matrix proteins versus coronally advanced flap technique: a 2-year report J Periodontol 2005;76(11):1871-1880.

Staffileno H. Management of Gingival Recession and Root Exposure Problems Associated With Periodontal Disease. Dent Clin North Am 1964;111-120.

Steiner GG, Person JK, Ainamo J. Change of the marginal periodontium as a result of labial tooth movement in monkeys. J Periodontol 1981;52(6):314-320.

Stewart DJ. Minor self-inflicted injuries to the gingiva. J Clin Periodontol 1976;3(2):128132

Stillman PR. Early clinical evidence of disease in the gingiva and the pericementum. $\mathrm{J}$ Dent Res 1921;3(3):25-31.

Stimmelmayr M, Allen EP, Gernet W, Edelhoff D, Beuer F, Schlee M. Treatment of gingival recession in the anterior mandible using the tunnel technique and a combination epithelial connective tissue graft Int J Periodontics Restorative Dent 2011;31(2):165-173.

Stoner JE, Mazdyasna S. Gingival recession in the lower incisor region of 15-year old subjects. J Periodontol 1980;51(2):74-76.

Sullivan HC, Atkins JH. Free autogenous gingival grafts. III. Utilization of grafts in the treatment of gingival recession. Periodontics 1968;6:152-160. 
Tal H, Moses O, Zohar R, Meir H, Nemcovsky C. Root coverage of advanced gingival recession: a comparative study between acellular dermal matrix allograft and subepithelial connective tissue grafts. J Periodontol 2002;73:1405-1411.

Tarnow DP. Semilunar coronally repositioned flap. J Clin Periodontol 1986;13:182-185.

Tatakis DN, Trombelli L. Gingival recession treatment: guided tissue regeneration with bioabsorbable membrane versus a connective tissue graft. J Periodontol 2000;71:299307.

Tinti C, Parma-Benfenati S. The free rotated papilla autograft: a new bilaminar grafting procedure for the coverage of multiple shallow gingival recessions. J Periodontol 1996;67:1016-1024.

Tozum TF, Keceli HG, Guncu N, Hatipoglu H, Sengun D. Treatment of gingival recession: Comparison of two techniques of subepithelial connective tissue graft. J Periodontol 2005;76(10):1842-1848.

Trombelli L, Scabbia A, Tatakis DN, Calura G. Subpedicle connective tissue graft versus guided tissue regeneration with bioabsorbable membrane in the treatment of human gingival recession defects. J Periodontol 1998;69:1271-1277.

Trombelli L, Scabbia A, Wikesjo UM, Calura G. Fibrin glue application in conjunction with tetracycline root conditioning and coronally positioned flap in the treatment of human gingival recession defects. J Clin Periodontol 1996;23:861-867.

U.S. Department of Health and Human Services, National Center for Health Statistics. NHANES III Reference Manuals and Reports (CD-ROM). Hyattsville, MD: Center for Disease Control and Prevention 1996

U.S. Department of Health and Human Services, National Center for Health Statistics. National Health and Nutrition Examination Survey, III 1988-94, NHANES III Examination Data File (CD-ROM). Hyattsville, MD: Center for Disease Control and Prevention 1997

Vergara JA, Caffesse RG. Localized gingival recessions treated with the original envelope technique: A report of 50 consecutive patients. J Periodontol 2004;75(10):13971403.

Wang HL, Bunyaratavej P, Labadie M, Shyr Y, MacNeil RL. Comparision of 2 clinical techniques for treatment of gingival recession. J Periodontol 2001;72:1301-1311. 
Ward V. A clinical assessment of the use of the free gingival graft for correcting localized recession associated with frena pull. J Periodontol 1974;45:78.

Wennström JL. Lack of association between width of attached gingiva and development of soft tissue recession. A five year longitudinal study. $J$ Clin Periodontol 1987;14(3):181-184

Wennström JL, Zucchelli G. Increased gingival dimensions. A significant factor for successful outcome of root coverage procedures? A 2-year prospective clinical study. J Clin Periodontol 1996;23:770-777.

Wilson TG, McGuire MK, Nunn ME. Evaluation of the safety and efficacy of periodontal applications of a living tissue-engineered human fibroblast--derived dermal substitute. II. Comparison to the subepithelial connective tissue graft: A randomized controlled feasibility study. J Periodontol 2005;76(6):881-889.

Woodyard JG, Greenwell H, Hill M, Drisko C, Iasella JM, Scheetz J. The clinical effect of acellular dermal matrix on gingival thickness and root coverage compared to coronally positioned flap alone. J Periodontol 2004;75:44-56.

Zabalegui I, Sicilia A, Cambra J, Gil J, Sanz M. Treatment of multiple adjacent gingival recessions with the tunnel subepithelial connective tissue graft: a clinical report. Int J Periodontics Restorative Dent 1999;19(2):199-206.

Zucchelli G, Amore C, Sforza NM, Mantobugnoli L. DeSanctis M. Bilaminar techniques for the treatment of recession-type defects. A comparative clinical study. J Clin Periodontol 2003;30:862-870.

Zucchelli G, Clauser C, DeSanctis M, Calandriello M. Mucogingival versus guided tissue regeneration procedures in the treatment of deep recession type defects. J Periodontol 1998;69:138-145.

Zucchelli G, DeSanctis M. Treatment of multiple recession-type defects in patients with esthetic demands. J Periodontol 2000;71:1506-1514.

Zucchelli G, DeSanctis M. Long-term outcome following treatment of multiple Miller Class I and II recession defects in esthetic areas of the mouth. J Periodontol 2005;76(12):2286-2292.

Zucchelli G, Mele M, Mazzotti C, Marzadori M, Montebugnoli L, De Sanctis M. Coronally advanced flap with and without vertical releasing incisions for the treatment of multiple gingival recessions: a comparative controlled randomized clinical trial. J Periodontol 2009;80(7):1083-94. 
Zucchelli G, Mele M, Stefanini M, Mazzoti C, Marzadori M, Montebugnoli L, de Sanctis M. Patient morbidity and root coverage outcome after subepithelial connective tissue and de-epithelialized grafts: a comparative randomized controlled clinical trial. J Clin Periodontol 2010;37:728-738. 


\begin{abstract}
APPENDIX A

\section{Presurgical measurements}

Measurements for probing depths, clinical attachment levels, and gingival margin levels will be taken at 6 sites on both buccal and lingual surfaces relative to the CEJ.
\end{abstract}

1. Mesial buccal line angle.

2. Mid-buccal.

3. Distal buccal line angle.

4. Mesial lingual line angle.

5. Mid-lingual.

6. Distal lingual line angle.

Measurements for the width of keratinized gingiva will be from the mid facial tooth surface.

Measurements for the gingival thickness will be taken mid-facial on test sites and control sites at the base of the sulcus and at the mucogingival junction level. 


\section{APPENDIX B}

\section{Surgical Measurements}

\section{A. Defect Height:}

All measurements made in relation to the CEJ.

1. CEJ to alveolar crest: From the CEJ to the alveolar crest measured at 3 points.

a. Mesial buccal line angle to the interproximal crest. (A)

b. Midbuccal CEJ to defect depth. (D)

c. Distal buccal line angle to the interproximal crest (C)

\section{B. Defect Width:}

1. Width of dehiscence defect, measured at the interproximal osseous crest. (B)

2. Width of dehiscence defect, measured $1.0 \mathrm{~mm}$ coronal to the defect depth. (E)

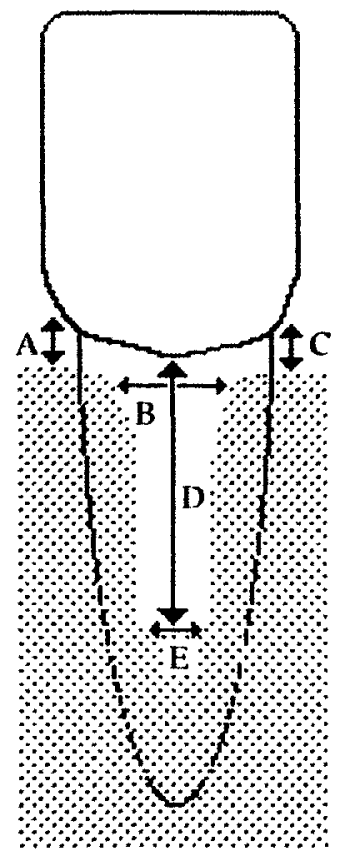




\begin{abstract}
APPENDIX C

\section{Recession Classification}

Miller's Classification (1985) of recession defects will be measured for the test and control sites. Scores will be recorded as follows:

Class I = Marginal tissue recession that does not extend to the mucogingival junction. There is no periodontal loss (bone or soft tissue) in the interdental area, and 100\% root coverage can be anticipated.

Class II = Marginal tissue recession which extends to or beyond the mucogingival junction. There is no periodontal loss (bone or soft tissue) in the interdental area, and 100\% root coverage can be anticipated.

Class III = Marginal tissue recession which extends to or beyond the mucogingival junction. Bone or soft tissue loss in the interdental area is present or there is malpositioning of the teeth that prevents the attempting of $100 \%$ root coverage. Partial root coverage can be anticipated.

Class IV $=$ Marginal tissue recession which extends to or beyond the mucogingival junction. The bone or soft tissue loss in the interdental area and/or malpositioning of teeth is so severe that root coverage cannot be anticipated.
\end{abstract}




\section{APPENDIX D}

\section{Plaque Index}

The plaque index of Silness and Loe (1964) will be measured for the test and control sites. The scores will be recorded as follows:

$0=$ No Plaque

$1=$ A film of plaque adhering to the free gingival margin and adjacent area of the tooth. The plaque may be seen in situ only after the application of disclosing solution or by using the probe on the tooth surface.

$2=$ Moderate accumulation of soft deposits within the gingival pocket, or on the tooth and gingival margin which can be seen with the naked eye.

$3=$ Abundance of soft matter within the gingival pocket and/or on the tooth and gingival margin.

Each gingival unit (mesiobuccal, buccal, distobuccal, distolingual, lingual, mesiolingual) of the tooth will be given a score $0-3$. The scores for each unit will be added together and divided by 6 to give the plaque index for that tooth. The score of the test tooth and the two adjacent teeth will be added and divided by 3 to give the plaque index for the test of control sites. 


\section{APPENDIX E}

\section{Gingival Index}

The Gingival Index (Lobene et al. 1986) will be measured. Scores will be as follows:

0 - Normal gingiva

1 - Mild inflammation - slight change in color, slight edema

2 - Moderate inflammation - redness, edema, and glazing.

3 - Severe inflammation - marked redness and edema. Ulceration.

Each gingival unit (buccal, lingual, mesiobuccal, distobuccal, mesiolingual, and distolingual) of the individual tooth will be given a score from $0-3$, called the gingival index for the area. The scores from the 6 areas of the tooth are added and divided by 6 to give the gingival index for the tooth. 


\section{APPENDIX F}

\section{Bleeding on Probing Index}

Bleeding on probing to the bottom of the pocket will be scored as follows:

$$
\begin{aligned}
& 0=\text { No bleeding } \\
& 1=\text { Bleeding. }
\end{aligned}
$$




\section{APPENDIX G}

\section{Keratinized Tissue}

The amount of keratinized tissue will be measured prior to treatment, and at the 6 month examination in order to determine if there is any change in the zone of keratinized tissue due to the treatment. The following calculation is the manner in which the width of keratinized tissue will be calculated.

\section{Width of Keratinized Tissue}

Initial Width $=$ GM1 to MGJ1

Final Width $=\mathrm{GM} 2$ to MGJ2

Change in Width $=$ Initial Width - Final Width

$\%$ Change in Width $=$ Change in Width $\times 100$

Initial Width 


\section{APPENDIX H}

\section{Tooth Mobility}

Miller proposed the following tooth mobility index:

$0=$ Movability of the crown within normal physiologic limits.

$1=$ Movability of the crown up to $0.5 \mathrm{~mm}$ in one direction, but does not exceed $1.0 \mathrm{~mm}$ in both directions.

$2=$ Movability of the crown from 0.5 to $1.0 \mathrm{~mm}$ in one direction, but does not exceed $2.0 \mathrm{~mm}$ in both directions.

$3=$ Movability of the crown exceeding $1.0 \mathrm{~mm}$ in one direction and/or vertical depressibility. Greater that $2.0 \mathrm{~mm}$ in both directions and/or vertical depressibility.

The index that will be used in the study is a modification of Miller's index (Laster et al. 1975), where half scores are used. Thus scores of $0,0.5,1.0,1.5,2.0,2.5$, and 3.0 will be utilized. 


\section{APPENDIX I}

\section{Creeping Attachment}

Creeping attachment (Goldman, 1964) is the result of the coronal migration of the grafted gingiva, taking place after the completed healing of the surgical site.

Root coverage will be determined by the amount of initial recession minus the final recession. The final recession will take into account the amount of creeping attachment that has occurred. The creeping attachment will be measured starting at 8 weeks post-operatively, and measured monthly until the 6-month examination. Creeping attachment has been shown to occur between 1 month and 1 or 2 years after surgical procedures.

The following calculation is the manner in which the amount of root coverage has been obtained:

\section{Amount of Root Coverage}

Initial Recession $=\mathrm{CEJ}-\mathrm{GM}_{1}$

Final Recession $=\mathrm{CEJ}-\mathrm{GM} 2$

Root Coverage $=$ Initial Recession - Final Recession

$\%$ Root Coverage $=\underline{\text { Root Coverage }} \times 1$

Initial Recession

Also reported will be:

Frequency of $100 \%$ root coverage

Frequency of $90 \%$ root coverage 


\title{
CURRICULUM VITAE
}

\author{
Marie-Eve Girouard, D.M.D.
}

EDUCATION University of Louisville, Graduate Periodontics Residency, Louisville, KY, 40292. July 2008-June 2011. Specialty Certificate Periodontics and MS Oral Biology.

Rotation Internal Medicine, University of Louisville Hospital. May 2009.

Rotation Anesthesiology, University of Louisville Hospital. June 2009.

University of Montreal Dental School (UDM), Montreal, Canada. July 2003-May 2008. Doctor of Dental Medicine.

Scuola Leonardo da Vinci, Rome, Italy. Summer 2007. Intensive Italian lessons.

Cegep de Maisonneuve, Montreal, Can. August 2000- December 2002. DEC in Psychology and Mathematics.

Collegio de Alicante, Alicante, Spain. Summer 2003.

Intensive Spanish lessons. Intermediate level Certificate.

\section{RESEARCH EXPERIENCE}

University of Louisville, Graduate Periodontics Residency, Louisville, KY, 40292. Root coverage comparing acellular dermal matrix to connective tissue graft using the coronally positioned tunnel technique (Master's Thesis; underway)

University of Louisville, Graduate Periodontics Residency, Louisville, KY, 40292. The Effect of a Laser Grooved Implant Collar Compared to a Standard Implant Collar on Peri-Implant Hard and Soft Tissue Healing. (Co-investigator) 
ACADEMIC AWARDS

Southern Academy of Periodontology 2nd Place Pennel Award. June 2011. Poster presentation at the summer annual meeting. Millenium Scholarship recipient 2003-2009.

TEACHING EXPERIENCE

Clinical Teaching Assistant, Clinical Periodontology Course, University of Louisville, 2009-2010.

Clinical Supervisor, Clinical Coverage of Periodontics for DMD Students, University of Louisville, 2009-2010.

SERVICE / ACTIVITIES

University of Montreal dental school representative 2003-2008.

PROFESSIONAL ASSOCIATIONS

American Association of Periodontology (AAP), 2008-present. Academy of Osseointegration (AO), 2009-present.

EMPLOYMENT Lifeguard at Montreal Institute of Cardiology. Montreal, Can. 1999-2005. 